\title{
Role of PI3K-AKT-mTOR Pathway as a Pro-Survival Signaling and Resistance-Mediating Mechanism to Therapy of Prostate Cancer
}

\author{
Thanakorn Pungsrinont, Julia Kallenbach and Aria Baniahmad *(D) \\ Institute of Human Genetics, Jena University Hospital, 07747 Jena, Germany; \\ thanakorn.pungsrinont@med.uni-jena.de (T.P.); julia.kallenbach@uni-jena.de (J.K.) \\ * Correspondence: aria.baniahmad@med.uni-jena.de; Tel.: +49-3641-9396820; Fax: +49-3641-99396822
}

check for updates

Citation: Pungsrinont, T.;

Kallenbach, J.; Baniahmad, A. Role of PI3K-AKT-mTOR Pathway as a Pro-Survival Signaling and Resistance-Mediating Mechanism to Therapy of Prostate Cancer. Int. J. Mol. Sci. 2021, 22, 11088. https:// doi.org/10.3390/ijms222011088

Academic Editors: Pavel Soucek and Isaac Kim

Received: 23 August 2021

Accepted: 11 October 2021

Published: 14 October 2021

Publisher's Note: MDPI stays neutral with regard to jurisdictional claims in published maps and institutional affiliations.

Copyright: (c) 2021 by the authors. Licensee MDPI, Basel, Switzerland. This article is an open access article distributed under the terms and conditions of the Creative Commons Attribution (CC BY) license (https:/ / creativecommons.org/licenses/by/ $4.0 /)$.

\begin{abstract}
Androgen deprivation therapy (ADT) and androgen receptor (AR)-targeted therapy are the gold standard options for treating prostate cancer (PCa). These are initially effective, as localized and the early stage of metastatic disease are androgen- and castration-sensitive. The tumor strongly relies on systemic/circulating androgens for activating AR signaling to stimulate growth and progression. However, after a certain point, the tumor will eventually develop a resistant stage, where ADT and AR antagonists are no longer effective. Mechanistically, it seems that the tumor becomes more aggressive through adaptive responses, relies more on alternative activated pathways, and is less dependent on AR signaling. This includes hyperactivation of PI3K-AKT-mTOR pathway, which is a central signal that regulates cell pro-survival/anti-apoptotic pathways, thus, compensating the blockade of AR signaling. The PI3K-AKT-mTOR pathway is well-documented for its crosstalk between genomic and non-genomic AR signaling, as well as other signaling cascades. Such a reciprocal feedback loop makes it more complicated to target individual factor/signaling for treating PCa. Here, we highlight the role of PI3K-AKT-mTOR signaling as a resistance mechanism for PCa therapy and illustrate the transition of prostate tumor from AR signaling-dependent to PI3K-AKT-mTOR pathway-dependent. Moreover, therapeutic strategies with inhibitors targeting the PI3K-AKT-mTOR signal used in clinic and ongoing clinical trials are discussed.
\end{abstract}

Keywords: prostate cancer; androgen receptor; castration-resistance; $\mathrm{AR}$ antagonist resistance; PI3K; $\mathrm{PKB} / \mathrm{AKT}$; $\mathrm{mTOR}$

\section{Introduction}

Over decades, prostate cancer ( $\mathrm{PCa}$ ) has been ranked as the most diagnosed malignancy and as the second leading cause of cancer-related mortality of men in many Western countries [1-3]. An increased risk of developing PCa is associated with multiple factors including age, heredity, race/ethnicity, and geography. PCa is an endocrine-related disease, in which male hormone androgens play an important role in PCa progression through activation of the androgen receptor (AR) [4,5]. This makes AR a major therapeutic target for PCa therapy. Yet, after a certain period of time with treatment, the tumor will eventually develop a resistance.

The relapse, or re-progression, of the tumor, usually via adaptive responses, relies on activated alternative pathways besides AR signaling [6-10]. This includes activation of PI3K-AKT-mTOR signaling, which is a well-known pathway that regulates multiple signal transductions and biological processes such as transcription, protein synthesis, metabolism, autophagy, cell proliferation, apoptosis, angiogenesis, migration, etc. [11-16]. In this review, we highlight the role of PI3K-AKT-mTOR signaling as a resistance mechanism for PCa therapy in both AR dependent and independent manners. We illustrate the transition of the prostate tumor from AR signaling-dependent towards PI3K-AKT-mTOR pathwaydependent. Moreover, therapeutic strategies with inhibitors targeting PI3K-AKT-mTOR signal used in clinic and ongoing clinical trials are reviewed. 


\section{PI3K-AKT-mTOR Signaling}

\subsection{PI3K}

PI3K, or phosphatidylinositol-3-kinase, is a plasma membrane-associated protein kinase that serves as a junction between the upstream growth factor/cytokine signals and the downstream intracellular signal transduction [11]. Among the three classes (I-III), class IA is most commonly linked to human cancer, including PCa [17]. This class of PI3K (referred to later as PI3K) is a heterodimer, which is formed by two functional subunits, a catalytic subunit (p110 $\alpha, \beta$, or $\delta$ isoform) and a regulatory subunit (p85 $\alpha, \mathrm{p} 55 \alpha, \mathrm{p} 50 \alpha, \mathrm{p} 85 \beta$, or $p 55 \gamma$ isoform) [18]. The catalytic subunit $p 110 \beta$ is suggested to be the most relevant isoform to PCa progression and resistance due to an association with basal AKT (protein kinase B) activation in PCa models $[17,19,20]$.

Usually, an activation of PI3K is mediated through receptor tyrosine kinases (RTKs), however, G-protein-coupled receptors and oncogenes, such as small GTPase RAS, can also activate PI3K, depending on the interaction context and the specificity towards PI3K subunits [21-24]. Once activated, PI3K phosphorylates phosphatidylinositol-4,5-biphosphate $\left(\mathrm{PI}(4,5) \mathrm{P}_{2}\right)$ to generate phosphatidylinositol-3,4,5-triphosphate $\left(\mathrm{PIP}_{3}\right)$. In addition, $\mathrm{PIP}_{3}$ can be further converted to phosphatidylinositol-3,4-biphosphate $\left(\mathrm{PI}(3,4) \mathrm{P}_{2}\right)$ by Src homology 2 (SH2) domain containing inositol polyphosphate 5-phosphatase 1/2 (SHIP1/2) [25].

On the one hand, $\mathrm{PIP}_{3}$ activates intracellular signaling by recruiting and binding to a variety of proteins, including phosphoinositide-dependent kinase 1 (PDK1) and AKT, that contain pleckstrin homology $(\mathrm{PH})$ domain [26]. This recruitment leads to the phosphorylation of AKT by PDK1 resulting in AKT activation. On the other hand, phosphorylation and activation of AKT by PDK1 can be facilitated by PI(3,4) $\mathrm{P}_{2}$ [25]. Notably, $\mathrm{PIP}_{3}$ can be inhibited via dephosphorylation by the tumor suppressor PTEN [27], whereas PI(3,4) $\mathrm{P}_{2}$ can be inhibited by both PTEN and INPP4B [28]. In PCa, loss or inactivation of PTEN and INPP4B seems to be common $[17,18,29,30]$.

\section{2. $A K T$}

AKT belongs to a family of serine/threonine protein kinases and is the most famous downstream effector of the PI3K. Yet, AKT can also be activated by other kinases independent of PI3K signaling, such as by IKKE, SRC, ACK1, TANK binding kinase 1, DNA-dependent protein kinase, and ATM [31], suggesting multiple crosstalk situations in the tumor cells. Activation of AKT has been shown to drive PCa formation in vivo [11,32]. Moreover, phospho-proteomic analysis showed that AKT was commonly found to be active in metastatic tumor samples collected from rapid autopsy [17,33]. AKT is fully activated when it is phosphorylated at both Thr308 and Ser473 sites. However, phosphorylation at either site alone is also sufficient for AKT to partially mediate a subset of downstream cellular signaling [34,35]. Activated AKT regulates multiple cellular processes by phosphorylating several targets, including TSC2, GSK3, FOXO, ASK1, IKK $\alpha$, CHK1, p27, p21, RAF1, BAD, MDM2, PRAS40, eNOS, AMPK, and WNK1 [36]. These downstream effectors link AKT activity to control protein synthesis, transcription, cell survival, apoptosis, proliferation, autophagy, and metabolism.

\section{3. $m$ TOR}

Mammalian target of Rapamycin or mTOR is a serine/threonine protein kinase and is one of the major downstream effectors of AKT signaling. Interestingly, mTOR is expressed at higher levels in PCa compared to benign samples [17,37]. mTOR interacts with different proteins and forms two distinct complexes, mTORC1 and mTORC2. mTORC1 is comprised of mTOR, mLST8, DEPTOR, TTI1, TEL2, RAPTOR, and PRAS40, while mTORC2 is a complex of mTOR, mLST8, DEPTOR, TTI1, TEL2, RICTOR, mSIN1, and PROTOR1/2 [18]. Notably, mTORC1 is sensitive towards Rapamycin-mediated inhibition, whereas mTORC2 is not.

The activation of $\mathrm{mTORC} 1$ signaling is triggered by AKT-mediated phosphorylation of TSC2, which inhibits the TSC1/2 complex, leading to an activation of mTORC1 activator GTP-bound RHEB [38]. Moreover, mTORC1 repressor PRAS40 (also in the complex) is 
inhibited by AKT-mediated phosphorylation [39-41]. Notably, AMPK, GSK3, WNT, and energy signals can regulate TSC2 as well, linking the TSC2-mTORC1 pathway with other signaling cascades [42,43]. Protein synthesis is the major biological process mediated by activated mTORC1 signal via phosphorylation and activation of p70S6 kinase (p70S6K) [44] and inhibition of 4EBP1 [45]. Activated mTORC1 also blocks autophagy by inhibiting the autophagy inducing complex ULK1/ATG13/FIP200 [46-48]. Other biological processes controlled by active mTORC1 include lipid synthesis, energy metabolism, and lysosome biogenesis [38].

The activity of mTORC 2 can be regulated by PI3K, RAS, AMPK, WNT, TSC $1 / 2$, and p70S6K [49-53]. Notably, inhibition of mTORC2 activity by p70S6K leads to a negative feedback regulation of the PI3K-AKT pathway, as mTORC2 facilitates AKT activation by phosphorylating Ser473 [54]. In contrast to biological processes controlled by mTORC1, active mTORC2 can phosphorylate several downstream effectors leading to cell survival, cell cycle progression, and actin remodeling. Moreover, it has been suggested that mTORC2 is required for the development of PCa lacking PTEN [55]. In line with this, the knockdown of PDK1 does not counteract enhanced PCa growth in PTEN-deficient transgenic mice [56], reflecting the possibility of mTORC2-mediated AKT and/or compensatory cascades activation.

Given the fact that the PI3K-AKT-mTOR pathway plays a critical role in controlling pro-survival cellular signals, it is possible that cancer cells, under therapeutic pressures, adaptively hyperactivate the pathway and its downstream cascades to compensate/overcome cellular stress. Pro-survival in general inhibits apoptosis, quiescence, and senescence, while promotes cell cycle progression. This may lead to even more aggressive cancer progression. In line with this, enhanced activity of PI3K-AKT-mTOR pathway correlates with PCa progression in the clinic [37,57-60]. Since feedback mechanisms activate pro-survival pathways, monotherapies using inhibitors of the PI3K-AKT-mTOR pathway could be limited in their efficacy.

\section{PI3K-AKT-mTOR Interplays in Genomic and Non-Genomic AR Signaling}

\subsection{AR and Genomic Signaling}

Inhibition of AR signaling is a major therapeutic aim in PCa therapy. Interestingly, the PI3K-AKT-mTOR pathway is well-documented for its crosstalk with AR signaling. Importantly, it may serve as a junction between genomic and non-genomic AR signaling.

AR is a transcription factor in a family of nuclear hormone receptor proteins. In general, inactive ARs reside in the cytoplasm of the cell and interact with chaperones and co-chaperones, such as heat shock proteins (HSPs) [61]. This interaction prevents AR from entering the nucleus. Canonically, initiation of the AR signaling begins with the binding of androgen to the ligand binding domain (LBD) of AR, which leads to a conformational change and AR activation (Figure 1). Hence, it can dissociate from chaperones, dimerize with another activated AR molecule, translocate into the nucleus, and bind to canonical androgen response element (ARE) for the regulating transcription of target genes. This is considered as "genomic AR signaling" and is ligand dependent, which is thought to occur over several hours [62]. Also, the activated AR can bind to non-canonical chromatin sites, with enhanced binding especially in cases of therapy resistance $[63,64]$. 

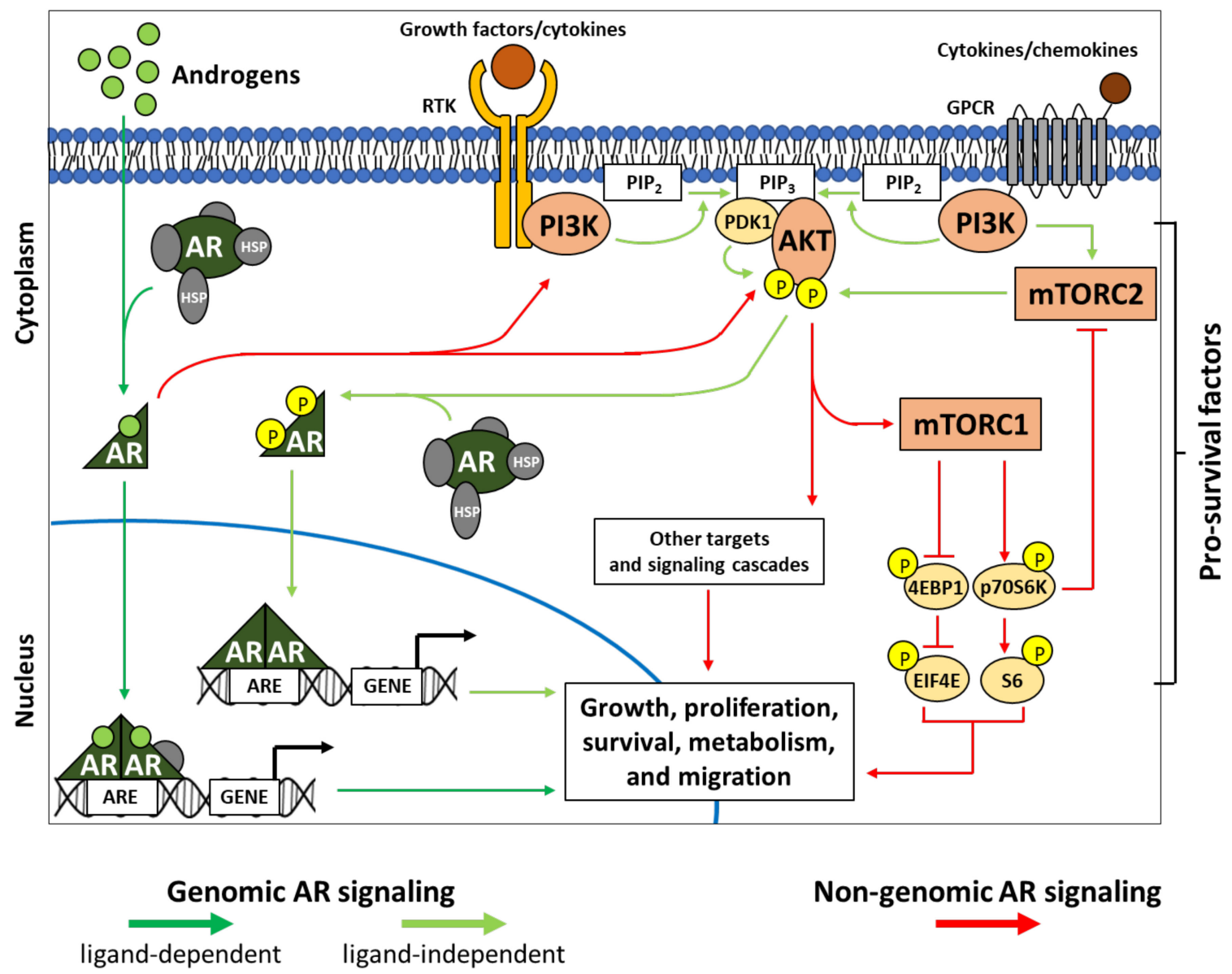

Figure 1. PI3K-AKT-mTOR interplays in genomic and non-genomic AR signaling. AR signaling can be classified into genomic and non-genomic signaling. Genomic AR signaling involves the translocation of activated AR into the nucleus, the binding to ARE of target genes, and the regulation of transcription activity. In contrast, non-genomic AR signaling does not require AR translocation and DNA binding. In general, AR activation is initiated from the binding of androgen to the receptor, which leads to conformational changes and dissociation of AR from chaperones such as HSPs. This is known as androgen- or ligand-dependent genomic signaling (dark green arrows). However, in the absence of androgens, AR can be activated via phosphorylation mediated by multiple cytoplasmic factors including AKT, a key biological processing factor of the PI3K-AKT-mTOR pathway. Thus, it is considered as ligand-independent genomic AR signaling (light green arrows). In turn, as non-genomic AR signaling (red arrows), the activation of AR can activate the PI3K-AKT-mTOR pathway by interacting with PI3K and AKT. Activation of PI3K-AKT triggers downstream effectors, including mTOR and other signaling cascades, leading to the promotion of growth, proliferation, survival, metabolism, migration, etc. $\mathrm{AKT}$, protein kinase $\mathrm{B} ; \mathrm{AR}$, androgen receptor; $\mathrm{ARE}$, androgen response element; EIF4E, eukaryotic translation initiation factor 4E; GPCR, G-protein-coupled receptor; HSPs, heat shock proteins; mTORC1/2, mammalian target of Rapamycin complex 1/2; P, phosphorylation; PDK1, phosphoinositide-dependent kinase 1; PI3K, phosphatidylinositol-3-kinase; PIP 2 , phosphatidylinositol-4,5-biphosphate; $\mathrm{PIP}_{3}$, phosphatidyl-inositol-3,4,5-biphosphate; p70S6K, p70S6 kinase; RTK, receptor tyrosine kinase; $\mathrm{S} 6$, ribosomal S6 protein; 4EBP1, 4E binding protein 1.

In the absence of androgens, genomic AR signaling can be regulated by cytoplasmic cascades, including the PI3K-AKT pathway, which are activated by various growth factors and cytokines [11,65-67] (Figure 1). In such cases, AR undergoes posttranslational modifications including phosphorylation, acetylation, methylation, ubiquitination, and SUMOylation [68]. The AR activated by transduction factors will eventually translocate into the nucleus and regulate target gene transcription. 


\subsection{AR and Non-Genomic Signaling}

AR signaling can also occur in a non-genomic manner triggered by androgen-bound AR (Figure 1), which has been shown to occur rapidly within minutes [69,70]. In nongenomic AR signaling, nuclear translocation and DNA binding of AR are not required. The activated cytoplasmic AR rather interacts with or functions through other molecular effectors in the cytoplasm or at the membrane lipid rafts [62,71-75]. This activates multiple signaling cascades leading to cell proliferation, survival, anti-apoptotic, and migration.

Several signaling molecules that are known to interact with AR include PI3K, AKT, SRC, RAS/RAF, PKC, MAPK/ERK, etc. [62,76]. Interestingly, these molecules, such as AKT, may serve as a junction between genomic and non-genomic AR signaling (Figure 1). Crossphosphorylation events between AKT and AR are an example. On one hand, androgenbound AR leads to an increase of AKT phosphorylation [77,78]. On the other hand, AKT phosphorylates AR at Ser210, Ser213, Ser215, Ser791, and Ser792 in order to regulate AR transcriptional activity and expression $[68,79,80]$. Thus, the downstream targets of those activated cascades triggered by non-genomic AR signaling may as well interact with nonligand-bound AR and eventually lead to an overlapping scheme of ligand-independent genomic AR signaling. This suggests that AR signaling can be compensated/overcome easily when the cell encounters some selective pressures.

\section{PI3K-AKT-mTOR in PCa Progression and AR-Targeted Therapy Resistance}

Application of therapeutic strategies against PCa depends on stages and particular situations of the disease. Also, the level of PCa diagnostic marker, prostate-specific antigen (PSA), is included in consideration. Surgery to remove the prostate gland (radical prostatectomy) may be the most effective option to remove the localized PCa that has low risk of progression to metastatic disease [81]. However, in some cases, due to the age, health issue, and refusion of patients, external beam radiation plus hormone therapy is rather chosen.

Localized PCa as well as the early stage of advanced/metastatic PCa are generally androgen- and castration-sensitive (CSPCa) (Figure 2; left panel). Huggins and Hodges's clinical observation in 1941 suggested that PCa growth can be controlled by reducing the level of androgens through castration [82]. Although basal activity of the PI3K-AKT-mTOR pathway should exist, the castration-sensitive characteristic indicates that these tumors are mainly relying on AR signaling. This observation brought up the current treatment option of androgen deprivation therapy (ADT) as a standard systemic hormone therapeutic strategy for PCa. ADT aims to lower serum testosterone concentration as much as possible in order to minimize stimulation of PCa cells [83]. ADT inhibits androgen production by blocking the hypothalamic-pituitary-testis feedback system with luteinizing hormonereleasing hormone analogues, also termed chemical castration. Adrenal ablating drugs are also used to decrease androgen synthesis from steroid precursors in the adrenal gland via inhibiting cytochrome P450 enzymes [83]. Unfortunately, despite the initial effectivity of $\mathrm{ADT}$, the tumor in many patients gradually develops into a stage of castration-resistant PCa (CRPCa) [84], which is usually at a metastatic level and a major cause of morbidity as well as mortality. 


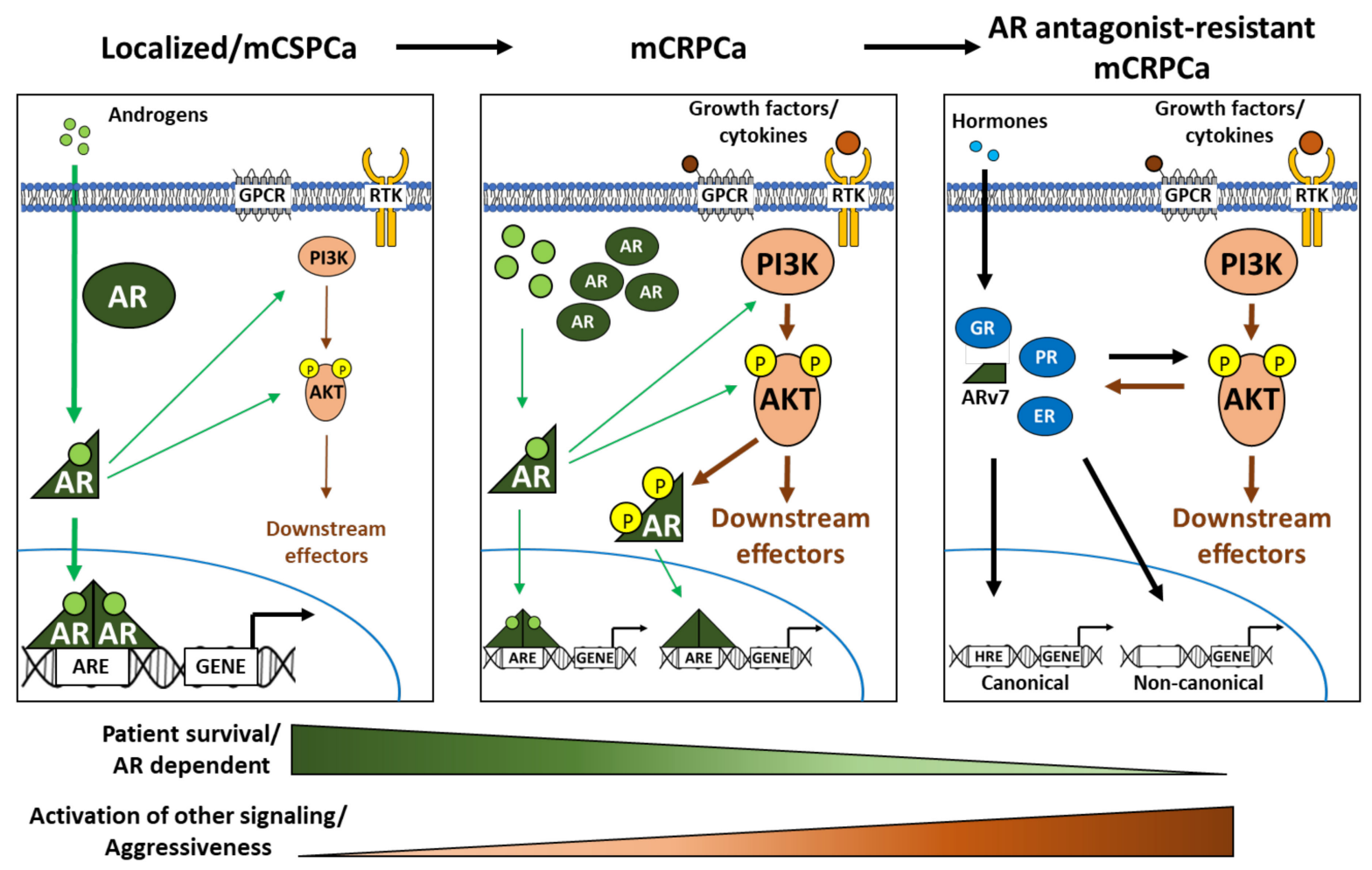

Figure 2. Transition from AR signaling-dependent to PI3K-AKT-mTOR pathway-dependent in PCa. PCa as a localized disease and at the early stage of metastatic disease is androgen- and castration-sensitive. The tumor at these stages strongly relies on systemic/circulating androgens for activating AR signaling to stimulate growth and progression (left panel). This makes it easy to suppress the tumor with therapeutic approaches that target androgen synthesis and AR signaling. However, after a certain period of time, the tumor will eventually develop a resistant stage called castration-resistance (middle panel). At this stage, ADT and the first generation of AR antagonists are not any more effective due to several hypothesized reasons, including intratumoral androgen synthesis, amplification of AR, activation of ligand-independent genomic AR signaling (e.g., via PI3K-AKT-mTOR), etc. These mechanisms suggest that the tumor at this stage still relies on AR signaling, although via adaptive responses, but could still be treated with second generation AR antagonists. Notably, bipolar androgen therapy (BAT) with cycling treatment of ADT and supraphysiological androgen levels seems to be also effective. Again, after a period of time, the tumor will become resistant to AR antagonist (right panel). Presumably, the therapeutic pressure by AR antagonists will selectively lead to the accumulation of PCa cells that no longer express AR or at least express mutated AR/AR splice variants (e.g., ARv7) lacking ligand binding domain. This makes the tumor insensitive to AR antagonists and BAT. Independent of AR, the tumor at this stage fully relies on hyperactivation of multiple cellular signaling cascades such as PI3K-AKT-mTOR and signaling of other nuclear hormone receptors (e.g., GR, PR, and ER). Along with more advance stages of the disease, an aggressiveness of the PCa is enhancing, whereas the survival of the PCa patient is reducing. AKT, protein kinase $\mathrm{B} ; \mathrm{AR}$, androgen receptor; $\mathrm{ARE}$, androgen response element; ARv7, androgen receptor splice variant 7; ER, estrogen receptor; GPCR, G-protein-coupled receptor; GR, glucocorticoid receptor; HRE, hormone response element; $\mathrm{mCSPCa}$, metastatic castration-sensitive prostate cancer; $\mathrm{mCRPCa}$, metastatic castration-resistant prostate cancer; P, phosphorylation; PI3K, phosphatidylinositol-3-kinase; PR, progesterone receptor; RTK, receptor tyrosine kinase.

Several mechanisms have been proposed for an occurrence of CRPCa, including increased intratumoral androgen synthesis, mutations of $\mathrm{AR}$, amplification/overexpression of AR, and crosstalk between AR and other signaling pathways such as PI3K-AKTmTOR [85,86] (Figure 2; middle panel). It seems that the tumor at this stage still relies on AR signaling, which is adaptively activated via multiple mechanisms [6-10]. For example, the activation of AR by AKT-mediated phosphorylation seems to generally occur in a lowtestosterone state $[79,87]$. Therefore, the inhibition of AR signaling with AR antagonists is still applicable. Hence, in order to achieve the fully blockade of AR signaling, AR antagonists are often employed along with ADT to treat both CSPCa and CRPCa [88,89]. First 
generation of AR antagonists, such as Flutamide and Bicalutamide, are used to treat CSPCa, whereas second generation AR antagonists, such as Enzalutamide, Apalutamide, and Darolutamide, are used against CRPCa. Yet, after a certain period of time with treatment, PCa will eventually develop a resistance against AR antagonists.

Interestingly, in contrast to an objective of inhibiting AR signaling, an application of using the supraphysiological androgen level (SAL) to treat CRPCa patients has been proposed as an optional therapeutic strategy [90]. Although, monotherapy of testosterone treatment showed disadvantages [91-93], combination therapy of SAL with ADT in a so-called bipolar androgen therapy (BAT) provided promising outcomes in clinical trials [94,95]. Importantly, it seems this therapy beneficially re-sensitizes CRPCa to AR antagonist treatment [95]. It is hypothesized that a rapid cycling between SAL and a depleted androgen level interfere with PCa cell adaptation on AR expression $[90,96]$.

On one hand, mutated AR within the LBD and AR splice variants that lack LBD may be accumulated in CRPCa under selective pressure with AR antagonist treatment [97], and thus, PCa becomes less sensitive to AR antagonists. On the other hand, PCa cells with no AR expression may also be accumulated $[98,99]$, and thus, the tumor progression is no longer dependent on AR signaling, such as the neuroendocrine prostate tumor [100]. Those cells may rely more on other nuclear hormone receptor signaling [101-103], or they may activate other AR independent signaling cascades $[18,104,105]$ (Figure 2; right panel). In such cases, BAT also may not be effective anymore. Other therapeutic options that are not targeting AR may be applied during this stage of disease including chemotherapy, signaling pathway inhibitors, DNA damage repair pathway inhibitors, and immunotherapy [106,107].

Notably, after each therapeutic resistance stage from localized CSPCa to metastatic CRPCa, it seems that the tumor becomes more aggressive through activated adaptive responses, relies more on those alternative pathways, and becomes less dependent on AR signaling. This includes hyperactivation and deregulation of PI3K-AKT-mTOR signaling. It has been reported that about $42 \%$ of localized-stage and $100 \%$ of advanced-stage exhibit a deregulated PI3K-AKT-mTOR signaling pathway [11,18,108-110].

\section{PI3K-AKT-mTOR Signaling Pathway as Resistance Mechanism to Therapy of PCa}

\subsection{Deregulation of PI3K-AKT-mTOR Signaling in PCa}

An oncogenic role of PI3K-AKT-mTOR signaling as well as common genetic alterations in this pathway are well-documented [18]. Thus, it is not surprising that the deregulation of this pathway would mediate resistance against therapy and support the tumorigenesis of PCa.

\subsubsection{PTEN Loss of Function}

One of the most common genetic alterations in prostate malignancies is the loss of tumor suppressor PTEN, which acts as a gatekeeper of the PI3K-AKT-mTOR pathway by dephosphorylating $\mathrm{PIP}_{3}$ back to $\mathrm{PI}(4,5) \mathrm{P}_{2}$, leading to the inhibition of cell growth $[17,18,29,111]$. Inactivation of PTEN by deletion or mutations correlate strongly with enhanced PI3K-AKTmTOR signaling, high Gleason score, and poor prognosis in advanced PCa [60,112-114]. It may occur in up to $50 \%$ of CRPCa cases [115]. Functional studies in vivo suggest PTEN loss as a genetic driver of murine prostate epithelium to become aggressive and locally invasive $\mathrm{PCa}$, which has the ability to eventually acquire castration-resistance characteristics [116-120]. Importantly, PTEN loss links the development of CRPCa with androgen insensitivity, and perhaps also with AR antagonist insensitivity. It has been shown that the loss of PTEN de-represses EGR1 and c-Jun, which are negative regulators of AR activity, leading to suppression of the transcription of androgen-responsive genes [118,121]. Yet, the loss of PTEN still promotes cell growth. These findings reflect that the loss of PTEN, which leads to the activation of PI3K-AKT-mTOR, could still promote PCa growth without the need of androgen to transactivate AR target genes, such as in case of ADT. Furthermore, studies from both in vivo and in vitro of PCa have shown that the loss of AR or treatment with AR antagonist Enzalutamide leads to enhanced AKT signaling [78,118,121], supporting an activation of PI3K-AKT-mTOR signal to resist AR targeted therapy. 


\subsubsection{PI3K Gain of Function}

Other deregulation of the PI3K-AKT-mTOR pathway along with PTEN loss includes gain of function of PI3K, AKT, and/or mTOR themselves either by mutation or amplification. As an upstream effector of the pathway, mutations in PIK3CA encoding catalytic subunit $\mathrm{p} 110 \alpha$ of PI3K is more common than the other isoforms. It has also been reported that approximately $30 \%$ of CRPCa patients harbor p $110 \alpha$ mutations [117]. Consistently, Pearson et al. (2018) has summarized across nine PCa genomic datasets and showed that up to $28 \%$ of cases exhibit high-level amplification [114]. Although an anti-proliferative as well as anti-tumor activity has been observed with p110 $\alpha$-specific PI3K inhibitors [122-124], the question remains whether $\mathrm{p} 110 \alpha$ is the major target in PCa therapy. This is due to a study of Pten loss-induced prostate tumor formation in mice, showing that the genetic deletion of $P i k 3 c b$ encoding $\mathrm{p} 110 \beta$ isoform, but not deletion of $P i k 3 c a$, inhibits tumorigenesis together with reduction of Akt phosphorylation [19]. Thus, it suggests that $\mathrm{p} 110 \beta$ and not $\mathrm{p} 110 \alpha$ may be more important isoform in PCa. Unlike p110 $\alpha$ and $\beta$, the mutation and amplification of the p1108 isoform are infrequently detected in PCa patients [18]. Yet, the inactivation of p1108 inhibited PI3K-AKT signaling as well as cell proliferation in p1108-highly expressed CRPCa cells [125], suggesting a potential target for a certain PCa subpopulation. In addition to alterations of the PI3K catalytic subunit, either genetic alterations or deletion of a regulatory subunit such as p $85 \alpha$ may in part promote PI3K-AKT-mTOR signaling. On the one hand, the p 85 regulatory subunit of PI3K suppresses p110 activity in the absence of stimuli, and on the other hand, p85-p110 heterodimerization is required after RTK activation for stimulating PI3K-AKT-mTOR signaling [18,22]. Importantly, it has been reported that both the $\mathrm{p} 110 \beta$ catalytic subunit and the $\mathrm{p} 85 \alpha$ regulatory subunit are also essential for AR transactivation and PCa progression [126].

\subsubsection{AKT Gain of Function}

Moving down to the key downstream effector of PI3K, gain of AKT function supports oncogenic, pro-survival/anti-apoptotic, and therapeutic resistant roles of this factor in PCa. Activation of AKT leads to the inhibition of cell death in the human CSPCa LNCaP cell line as well as promotes tumor growth and castration-resistance in transgenic mice [32,127]. Interestingly, gain of function of AKT seems to associate more with a high-level of $A K T$ amplification than a mutation of $A K T$, since $A K T$ amplification is more frequently detected [18]. In line with this, genetic alterations of well-known AKT regulators such as PDK1, PHLPP1/2, and PP2A may contribute also to the gain of AKT function [128,129]. An activation of AKT can be detected by the phosphorylation levels of Ser473 and Thr308. Surprisingly, either AR agonist at SAL used in BAT or the AR antagonist Enzalutamide used in clinic not only inhibit cell proliferation, but also enhance AKT phosphorylation in a cell culture model [78], rendering human CSPCa LNCaP cells to become apoptotic resistant. This in vitro model may represent an initial development of AR-independent CRPCa.

One underlying mechanism of AR antagonist-induced AKT phosphorylation could be the regulation of FKBP5 transcription, which is an AR-transactivated target. As an HSP90associated co-chaperone that regulates the responsiveness of steroid hormone receptors, FKBP5 has been shown to negatively regulate AKT signaling by stabilizing the protein phosphatases PHLPP1/2 [121,130]. This means suppression of AR-mediated transactivation of $F K B P 5$ enhances AKT phosphorylation. It is also suggested that ADT stimulates AKT signaling for prostate tumor survival partly through FKBP5 downregulation [121,131]. Hence, reduced expression of FKBP5 during ADT or AR-targeted therapy would lead to enhanced AKT activation and may facilitate the resistance to those therapies. In line with this, an increased level of AKT phosphorylation correlates with high Gleason grade and poorer survival in CRPCa $[57,132,133]$. Moreover, in combination with PTEN loss and high Gleason score, increased phosphorylation level of AKT can also be used to predict biochemical recurrence after radical prostatectomy [134]. 


\subsubsection{1. mTOR Gain of Function}

Genetic alterations of mTORC1/2 upstream regulators TSC $1 / 2$ can lead to mTOR gain of function. On one hand, deletion of Tsc1 in murine prostate epithelium causes prostate neoplasia, which is associated with elevated mTORC1 signaling [135]. On the other hand, the combined loss of heterozygous $\mathrm{Tsc}^{+/-}$and $\mathrm{Pten}^{+/-}$is sufficient to promote mTOR activation and prostate tumorigenesis in vivo [136]. Apart from upstream regulators, genetic alterations of mTORC1/2 components themselves should not be overlooked. Interestingly, although the frequency of genetic alterations of other components is low in PCa, DEPTOR gene amplification appears to be frequently detected in up to $21.4 \%$ of cases and correlates with worse disease/progression-free survival [18]. This is surprising, since DEPTOR is actually an endogenous suppressor of mTOR kinase activity. One possible explanation would be that DEPTOR upregulation suppresses the feedback inhibition of mTORC1-p70S6K signal towards mTORC2 and PI3K, resulting in turn in an increased activation of AKT and mTORC1-independent functions [137-139]. Another important factor is RICTOR, a main component of mTORC2, which makes mTORC2 insensitive to Rapamycin. It has been reported that Rictor is required for prostate tumorigenesis induced by Pten loss in mice [55]. This is supported by in vivo studies showing that loss of Rictor suppresses Pten-deleted PCa growth. Therefore, it suggests that the oncogenic alteration of RICTOR that causes mTORC2 gain of function could potentially facilitate PCa progression.

\subsection{PI3K-AKT-mTOR as a Pro-Survival/Anti-Apoptotic Signaling}

The most important key player for the pro-survival/anti-apoptotic role of PI3KAKT-mTOR pathway appears to be AKT. It exerts multiple mechanisms to control cell survival and apoptosis by interacting directly with proteins of the apoptotic pathway or by regulating transcription factors that transcribe apoptotic-controlled genes [140].

One of the direct substrates of AKT is BAD, which is a pro-apoptotic factor and a member of the BCL-2 family of proteins that binds to and inhibits anti-apoptotic factor BCL-2 or BCL-XL. Inactivation of BAD occurs through phosphorylation at Ser136 by active AKT [141], leading to an activation of BCL-2 or BCL-XL and cell survival. In CRPCa, it has been reported that PI3K-AKT signaling is activated by the clinically used AR antagonist Enzalutamide, facilitating cells to evade apoptosis via BAD inactivation [142]. This suggests one possible mechanism of how CRPCa cells become AR antagonist resistant.

Other apoptotic pathway regulators that interact and become phosphorylated by AKT are the cell death protease Caspase- 9 and apoptosis signal-regulating kinases ASK1, MLK3, and SEK1 [140]. AKT phosphorylates Caspase-9 at Ser19 and inhibits its protease activity [143]. AKT phosphorylates on Ser83 of ASK1, Ser674 of MLK3, and Ser78 of SEK1, causing these factors to be inactive [144-147]. These AKT activities result in the inhibition of apoptosis induction and promotion of cell survival.

In PCa, AKT-mediated ASK1 inhibition may be critical for cell survival. It is suggested that the HSP90 chaperone is required for AKT-mediated phosphorylation and inhibition of ASK1 [145]. Interestingly, the HSP90 inhibitor sensitizes CSPCa LNCaP cells to apoptosis under the treatment with SAL used in BAT [78]. In line with this, SAL-treated LNCaP cells, although at the growth arrest stage, exhibit apoptotic resistance by enhancing the AKTmTOR pathway. In CRPCa and AR antagonist-resistant CRPCa, AKT-mediated ASK1 also seems to be important. It has been shown in C4-2 as well as PC 3 cells that disabled homolog 2-interacting protein (DAB2IP) coordinates both PI3K-AKT and ASK1 pathways for cell survival and apoptosis [148]. Gain of function of this protein can suppress the PI3K-AKT pathway and enhance ASK1 activation, leading to cell apoptosis, whereas loss of function of DAB2IP leads to opposite effects. Loss of DAB2IP has also been shown to accelerate PCa growth in vivo [148]. Notably, loss of DAB2IP is often detected in androgen-independent PCa $[149,150]$.

Apart from directly regulating the proteins of the apoptotic pathway, AKT is able to regulate cell survival and anti-apoptosis via transcription factors. This includes phosphorylation of FOXO1/2/3/4, IKB kinase, MDM2, CREB, YAP, and AR. By phosphorylating 
FOXO, IKB kinase, and CREB, AKT indirectly controls transcription machinery of apoptosis regulating genes by suppressing pro-apoptotic factors of the BCL-2 family, as well as promoting anti-apoptotic factors of the BCL-2 family and caspase inhibitors [140]. Phosphorylated YAP by AKT suppresses apoptosis mediated by p73-regulated pro-apoptotic gene transcription [151]. Moreover, AKT-induced phosphorylation and translocation of MDM2 from the cytoplasm to the nucleus. Thus, AKT results in an inactivation/degradation of p53 and thereby antagonizes p53-mediated pro-apoptotic transcriptional regulation [152-154].

Interestingly, the PI3K-AKT pathway inhibits not only apoptosis but also triggers $\mathrm{G}_{1} / \mathrm{S}$ cell cycle progression. It is known that AKT phosphorylates and inhibits GSK3 $\beta$ to prevent cyclin D1 degradation [155]. Moreover, the PI3K-AKT pathway also directly affects the cell cycle inhibitor $\mathrm{p} 21^{\text {Waf1/Cip } 1}$ and $\mathrm{p} 27^{\mathrm{Kip} 1}$ by phosphorylation that causes cytoplasmic accumulation and inhibition of the access to the cyclin-CDK targets $[156,157]$.

As a downstream effector of the PI3K-AKT-mTOR pathway, mTORC1/2 are also involved in cell survival and anti-apoptosis regulation [14]. Via multiple signaling cascades, including AKT activation as described in previous sections, mTORC2 is well-linked to a role regarding cell survival/anti-apoptosis [158-160]. Unlike mTORC2, mTORC1 is more well-known for its role in ribosomal biogenesis and protein translation, yet these are important processes for cancer cell survival and proliferation [161].

Several studies have implicated mTORC1 in apoptosis and cell survival regulation [162-165]. For example, it has been described that mTOR regulates cell survival after etoposide treatment in acute myeloid leukemia cells (AML) [162]. Furthermore, a recent study showed that inhibition of mTORC1 improved the killing of AML cells by chemotherapy in a time-specific manner [165]. In mouse embryonic fibroblasts (MEFs), mTORC1 can control mitochondrial dynamics and cell survival via MTFP1 [164]. In PCa cells, SAL-treated cells that are apoptosis resistant are accompanied by enhanced phosphorylation of both AKT and ribosomal S6 proteins [78], suggesting an enhanced mTORC1 activity under SAL condition. In line with this, inhibition of AKT does not abolish SAL-induced S6 phosphorylation, suggesting an AKT bypassing mechanism by activated AR. Interestingly, the phosphorylation state of ribosomal S6 protein, a target of mTORC1 downstream effector p70S6K, is implicated with cell survival [166-168]. MEFs carrying S6 ${ }^{\mathrm{P}-/-}$ are sensitive to TRAIL-, etoposide-, and MG132-induced apoptosis $[167,168]$. This suggests that several factors within the PI3K-AKT-mTOR pathway possess, individually in an autonomous manner, pro-survival activity.

\section{Targeting PI3K-AKT-mTOR Signaling in PCa}

Since the PI3K-AKT-mTOR pathway is commonly activated in advanced stages of $\mathrm{PCa}$, this pathway may represent a potential target to effectively inhibit PCa growth and to overcome resistance of AR targeted therapy [11,169]. Many inhibitors for this pathway have been tested as monotherapy or in combination with other agents in preclinical and clinical trials as discussed below and summarized in Table 1. 
Table 1. PI3K-AKT-mTOR pathway inhibitors used in clinical trials.

\begin{tabular}{|c|c|c|c|c|c|c|}
\hline Target & Agent & Phase & Regimen & Population & Status & Registry \\
\hline \multirow{5}{*}{$\begin{array}{l}\text { Pan-PI3K } \\
\text { inhibitors }\end{array}$} & \multirow{4}{*}{$\begin{array}{c}\text { BKM120 } \\
\text { (Buparlisib) }\end{array}$} & I & $\begin{array}{l}\text { +Abiraterone acetate } \\
\text { (CYP17A1 inhibitor) }\end{array}$ & $\begin{array}{l}\text { CRPCa progressed on } \\
\text { Abiraterone acetate }\end{array}$ & Completed & NCT01634061 \\
\hline & & I & + Abiraterone acetate & $\begin{array}{l}\text { Docetaxel -pretreated } \\
\text { metastatic CRPCa }\end{array}$ & Terminated & NCT01741753 \\
\hline & & II & Monotherapy & $\begin{array}{l}\text { Metastatic CRPCa } \\
\text { progressed following ADT } \\
\text { and chemotherapy }\end{array}$ & Terminated & NCT01385293 \\
\hline & & II & Monotherapy & $\begin{array}{l}\text { High-risk, localized } \\
\text { prostate cancer prior to } \\
\text { radical prostatectomy }\end{array}$ & Terminated & NCT01695473 \\
\hline & $\begin{array}{c}\text { PX866 } \\
\text { (Sonolisib) }\end{array}$ & II & Monotherapy & $\begin{array}{c}\text { Metastatic CRPCa } \\
\text { progressed following ADT }\end{array}$ & Completed & NCT01331083 \\
\hline \multirow{3}{*}{$\begin{array}{c}\text { Dual PI3K/ } \\
\text { mTOR } \\
\text { inhibitors }\end{array}$} & BEZ235 & I & + Abiraterone acetate & $\begin{array}{l}\text { CRPCa progressed on } \\
\text { Abiraterone acetate }\end{array}$ & Completed & NCT01634061 \\
\hline & GDC-0980 & II & +Abiraterone acetate & $\begin{array}{c}\text { Docetaxel pre-treated } \\
\text { CRPCa }\end{array}$ & $\begin{array}{l}\text { Active, not } \\
\text { recruiting }\end{array}$ & NCT01485861 \\
\hline & LY3023414 & II & +Enzalutamide & Metastatic CRPCa & Completed & NCT02407054 \\
\hline \multirow{10}{*}{$\begin{array}{c}\text { AKT } \\
\text { inhibitors }\end{array}$} & \multirow{3}{*}{$\begin{array}{l}\text { AZD5363 } \\
\text { (capi- } \\
\text { vasertib) }\end{array}$} & I & Monotherapy & Metastatic CRPCa & Completed & NCT01692262 \\
\hline & & I & $\begin{array}{l}+ \text { Enzalutamide or } \\
\text { Abiraterone }\end{array}$ & Metastatic CRPCa & Completed & NCT04087174 \\
\hline & & $\mathrm{I} / \mathrm{II}$ & $\begin{array}{l}+ \text { Docetaxel and } \\
\text { Prednisolone } \\
\text { (glucocorticoid) }\end{array}$ & Metastatic CRPCa & $\begin{array}{l}\text { Active, not } \\
\text { recruiting }\end{array}$ & NCT02121639 \\
\hline & $\begin{array}{l}\text { GSK2141795 } \\
\text { (Upros- } \\
\text { ertib) }\end{array}$ & $\mathrm{I}$ & Monotherapy & $\begin{array}{l}\text { Castration-resistant, locally } \\
\text { advanced or metastatic } \\
\text { with/without PTEN loss }\end{array}$ & Completed & NCT00920257 \\
\hline & \multirow[t]{2}{*}{ MK2206 } & II & $\begin{array}{l}\text { +Bicalutamide } \\
\text { (anti-androgen) }\end{array}$ & $\begin{array}{l}\text { PCa patients with } \\
\text { biochemical relapse and } \\
\text { rising PSA after primary } \\
\text { therapy }\end{array}$ & $\begin{array}{l}\text { Active, not } \\
\text { recruiting }\end{array}$ & NCT01251861 \\
\hline & & I & +Hydroxychloroquine & Stage III PCa & $\begin{array}{l}\text { Active, not } \\
\text { recruiting }\end{array}$ & NCT01480154 \\
\hline & \multirow{3}{*}{$\begin{array}{l}\text { GDC-0068 } \\
\text { (Ipatasertib) }\end{array}$} & II & $\begin{array}{l}\text { +Abiraterone acetate } \\
\text { and Prednisone }\end{array}$ & $\begin{array}{l}\text { Metastatic or advanced } \\
\text { prostate carcinoma }\end{array}$ & $\begin{array}{l}\text { Active, not } \\
\text { recruiting }\end{array}$ & NCT01485861 \\
\hline & & $\mathrm{Ib}$ & $\begin{array}{c}\text { +Atezolizumab and } \\
\text { Docetaxel }\end{array}$ & Metastatic CRPCa & Recruiting & NCT04404140 \\
\hline & & III & $\begin{array}{l}+ \text { Abiraterone acetate }+ \\
\text { Prednisone/Prednisolone }\end{array}$ & Metastatic CRPCa & $\begin{array}{l}\text { Active, not } \\
\text { recruiting }\end{array}$ & NCT03072238 \\
\hline & Perifosine & II & Monotherapy & $\begin{array}{c}\text { Metastatic } \\
\text { androgen-independent } \\
\text { PCa }\end{array}$ & Completed & NCT00060437 \\
\hline \multirow{4}{*}{$\begin{array}{l}\text { mTORC1 } \\
\text { inhibitors }\end{array}$} & \multirow{4}{*}{ Everolimus } & II & Monotherapy & Metastatic CRPCa & Completed & NCT00629525 \\
\hline & & I & +Radiation therapy & $\begin{array}{l}\text { Biochemical recurrence } \\
\text { after radical prostatectomy }\end{array}$ & Completed & NCT01548807 \\
\hline & & II & $\begin{array}{l}\text { +Pasireotide } \\
\text { (somatostatin) }\end{array}$ & $\begin{array}{c}\text { Chemotherapy-naive } \\
\text { CRPCa }\end{array}$ & Terminated & NCT01313559 \\
\hline & & $\mathrm{I} / \mathrm{II}$ & $\begin{array}{c}\text { +Docetaxel, } \\
\text { Bevacizumab (VEGF } \\
\text { inhibitor) }\end{array}$ & Metastatic CRPCa & Completed & NCT00574769 \\
\hline
\end{tabular}


Table 1. Cont

\begin{tabular}{|c|c|c|c|c|c|c|}
\hline Target & Agent & Phase & Regimen & Population & Status & Registry \\
\hline & & $\mathrm{I} / \mathrm{II}$ & +Docetaxel & Metastatic CRPCa & Completed & NCT00459186 \\
\hline & & II & $\begin{array}{l}+ \text { Carboplatin and } \\
\text { Predisone }\end{array}$ & $\begin{array}{c}\text { Metastatic CRPCa } \\
\text { progressed after Docetaxel }\end{array}$ & Completed & NCT01051570 \\
\hline & & II & +Bicalutamide & $\begin{array}{l}\text { Recurrent or metastatic } \\
\text { CRPCa after first-line ADT }\end{array}$ & Completed & NCT00814788 \\
\hline & \multirow{6}{*}{ Temsirolimus } & $\mathrm{I} / \mathrm{II}$ & +Bevacizumab & $\begin{array}{l}\text { Chemotherapy-treated } \\
\text { metastatic CRPCa }\end{array}$ & Completed & NCT01083368 \\
\hline & & II & Monotherapy & $\begin{array}{l}\text { Chemotherapy-treated } \\
\text { metastatic CRPCa }\end{array}$ & Terminated & NCT00887640 \\
\hline & & II & Monotherapy & $\begin{array}{l}\text { Chemotherapy-naive } \\
\text { metastatic CRPCa }\end{array}$ & Completed & NCT00919035 \\
\hline & & I & $\begin{array}{c}\text { +Vorinostat (HDAC } \\
\text { inhibitor) }\end{array}$ & Metastatic CRPCa & Terminated & NCT01174199 \\
\hline & & $\mathrm{I} / \mathrm{II}$ & +Docetaxel & $\begin{array}{c}\text { CRPC receiving first-line } \\
\text { docetaxel }\end{array}$ & Completed & NCT01206036 \\
\hline & & $\mathrm{I} / \mathrm{II}$ & +Cixutumumab & Metastatic CRPCa & Completed & NCT01026623 \\
\hline \multirow{3}{*}{$\begin{array}{c}\text { Dual } \\
\text { mTORC1/2 } \\
\text { inhibitors }\end{array}$} & MLN0128 & II & Monotherapy & Metastatic CRPCa & Completed & NCT02091531 \\
\hline & \multirow{2}{*}{ AZD2014 } & I & Monotherapy & $\begin{array}{l}\text { High-risk PCa before } \\
\text { radical prostatectomy }\end{array}$ & Completed & NCT02064608 \\
\hline & & I & $\begin{array}{c}\text { Monotherapy/+ } \\
\text { Abiraterone acetate }\end{array}$ & CRPCa & Completed & NCT01884285 \\
\hline
\end{tabular}

+ indicates co-treatment of agent and indicated regimen. ADT, androgen deprivation therapy; CRPCa, castration-resistance prostate cancer; $\mathrm{PCa}$, prostate cancer.

\subsection{PI3K Inhibitors}

Inhibitors of PI3K can be divided/classified into pan-PI3K inhibitors and isoformspecific PI3K inhibitors. Pan-PI3K inhibitors target the catalytic subunit of all three isoforms of class IA PI3K. One potent oral pan-PI3K inhibitor is BKM120, which suppressed tumor growth in PC3-xenograft mouse model [170]. An $\mathrm{IC}_{50}$ of BKM120 at $3.23 \mu \mathrm{M}$ and $2.81 \mu \mathrm{M}$ has been documented for human CSPCa LNCaP cell line and AR antagonist-insensitive CRPCa PC3 cell line, respectively [171]. The inhibitor showed evidence of partial response in one out of 21 patients in a phase I first-in-men study, and seven patients remained on treatment for $\geq 8$ month [172]. BKM120 is currently under investigation in metastatic CRPCa in a phase II study. PX866 is a synthetic derivative of wortmannin, which covalently binds to Lys802 in the ATP catalytic site of the PI3K [173]. In a phase II study PX866 was well tolerated in patients with recurrent or metastatic CRPCa, and 14 of 25 patients were progression-free at 12 weeks [174]. However, the clinical use of pan-PI3K inhibitors in monotherapies is limited by the compensatory increase in AR signaling [121].

Isoform-specific PI3K inhibitors, such as BYL719 and MLN1117, aim to specifically target the p110 isoform to decrease side effects like insulin resistance and hyperglycemia. Targeting p110 might be an effective treatment option since PIK3CA, the gene that encodes $p 110 \alpha$, is commonly altered in metastatic PCa. In line with this, both inhibitors indicated antiproliferative and antitumor activity in cell lines and xenograft models with PIK3CA mutations [122,123]. However, compensatory effects by other PI3K isoforms can occur and will eventually lead to an activation of other pro-survival pathways including re-activation of AR-signaling. This highlights the need to target, in addition to blockage of androgen action, the androgenindependent receptor activation as well as pro-survival cancer cell pathways. 


\subsection{AKT Inhibitors}

As key regulator of pro-survival pathways, AKT provides an attractive target for therapeutic interventions. AKT inhibitors can be categorized based on their mechanism of action into six classes [175]. The first class comprises ATP-competitive inhibitors of AKT such as Ipatasertib and AZD5363 [176]. This kind of inhibitors, unlike allosteric inhibitors, lead to hyperphosphorylation of AKT at the Thr308 and Ser473 residues. Lipid-based AKT inhibitors that prevent the generation of $\mathrm{PIP}_{3}$ by PI3K represent the second class. Different phosphatidylinositol analogs, such as Calbiochem AKT inhibitors (Sigma Aldrich, Cat.-Nr.: 124005, St. Louis, MO, USA ), and PI3K inhibitors, such as PX-866, use this mechanism of action [177]. The third class consists of compounds named pseudo-substrate inhibitors, including AKTide-2 T and FOXO3 hybrid [178,179]. The fourth class is made of allosteric inhibitors of the kinase domain of AKT, such as MK-2206. Importantly, antibodies can also be used to inhibit AKT activity and thus represent the fifth class. The last class of inhibitors targets the PH-domain of AKT to interfere with the translocation of AKT to the plasma membrane and therefore blocking AKT phosphorylation and activation. This class includes compounds such as PX-316 [175]. Despite the large number of AKT inhibitors only allosteric and ATP-competitive AKT inhibitors have so far reached the clinical phase for PCa.

Importantly, preclinical studies with the allosteric AKT inhibitor Perifosine reduced proliferation and induced apoptosis and differentiation in PC3 [180] and PTEN-deficient PCa cells [181]. In LNCaP and PC 3 cells, an $\mathrm{IC}_{50}$ of Perifosine is $\sim 5 \mu \mathrm{M}$, whereas DU145 cells exhibit an $\mathrm{IC}_{50}$ value of $15 \mu \mathrm{M}$ [181]. Perifosine is an alkylphospholid that accumulates in cell membranes; however, besides the AKT inhibitory properties, the exact mechanism of action of this inhibitor remains unknown [17]. In men with CRPCa, Perifosine was well-tolerated but lacked evidence of a radiographic or PSA response [182]. Another clinically tested allosteric inhibitor is MK-2206 [176]. This inhibitor predominantly targets AKT1 $\left(\mathrm{IC}_{50}=5 \mathrm{nM}\right)$ and AKT2 $\left(\mathrm{IC}_{50}=12 \mathrm{nM}\right)$ with lower potency against AKT3 $\left(\mathrm{IC}_{50}=65 \mathrm{nM}\right)$ [183]. MK-2206 has in vitro and in vivo antitumor activity [183].

Recent studies suggest that active site AKT inhibitors may have greater antitumor activity. In line with this hypothesis, the active site inhibitor AZD5363 was reported to suppress proliferation and to increase apoptosis in PCa cell lines and the LNCaP xenograft model [184]. An IC 50 of AZD5363 in LNCaP cells is at nanomolar concentrations [185]. Moreover, a report from a phase I study has suggested that the combination of AZD5363 and AR antagonist Enzalutmide is tolerable and has antitumor activity [186]. The sensitivity towards AZD5363 is correlated with the presence of PIK3CA mutations, AKT1 1 E17K mutations, or PTEN loss [185]. Especially, the combination of AZD5363 with Docetaxel led in $70 \%$ of men with metastatic CRPCa to $>50 \%$ reduction of PSA levels illustrating the potential of active site inhibitors in combination therapy [187].

The optimization of ATP-competitive AKT inhibitors led to the development of Ipatasertib (GDC-0068), a highly selective AKT1-3 inhibitor with an IC50 value of 5, 18, and $8 \mathrm{nM}$, respectively. Currently, Ipatasertib is evaluated in a phase 3 trial in combination with Abiraterone and prednisolone in metastatic CRPCa (NCT03072238). Importantly, the pan-AKT inhibitor GSK2141795 (Uprosertib) showed measurable responses in a phase I study of seven patients, while six men had a stable disease [188]. Moreover, Uprosertib as monotherapy was reported to be safe and well-tolerated at the recommended phase II dose study [189]. These results demonstrate the clinical potential of AKT inhibitors in a special subset of patients. However, a major issue of many AKT inhibitors is the relief of negative feedback inhibition and activation of different RTKs [190]. Hence, inhibitors have been developed that target the downstream mediators of AKT.

\section{3. mTOR Inhibitors}

The mTOR is an important downstream effector of the PI3K pathway, which integrates extracellular signal transduction with metabolic processes representing a potent target to control cellular growth. The allosteric mTORC1 inhibitors Rapamycin and its analogs, including Everolimus and Temsirolimus (Table 1), were the first PI3K/AKT/mTOR path- 
way inhibitors that were assessed in clinical trials [169]. Pre-clinical studies of mTORC1 inhibitors were promising and reverted prostatic intraepithelial neoplasia (PIN) in mouse models overexpressing AKT [191]. However, clinical trials using single mTORC1 inhibitors lacked favorable clinical responses [192,193]. Rapamycin demonstrated successful inhibition of the mTORC1 target phospho-S6 in patients with intermediate to high-risk PCa, but no significant effects on tumor cell proliferation, induction of apoptosis, or PSA levels were observed [194]. This may be due to mTORC2 mediated compensation and activation of AKT $[169,195]$. Further, Rapalogs showed incomplete inhibition of downstream effectors, including EIF4E, since Rapalogs do not bind directly to and inhibit the catalytic core of the mTOR kinase. Instead, they bind to FKBP12 to allosterically inhibit mTOR [196].

Next, a new class of mTOR inhibitors blocking mTORC1 and mTORC2 activity have been developed with the aim to prevent the feedback induction of AKT. The dual mTORC1/2 inhibitors, such as MLN0128 and AZD2014, demonstrated improved efficiency due to a more potent inhibition of downstream targets like 4EBP1, protein synthesis and induction of cell cycle arrest in different cell lines [197]. In addition, MLN0128 prevented not only PCa invasion and metastasis, but further induced apoptosis [198]. This inhibitor has been previously tested in a phase II study in advanced CRPCa [199]. Interestingly, AZD2014 inhibited migration, invasion, and EMT progression in Docetaxel-sensitive and Docetaxel-resistant CRPCa cells more potent compared to Rapamycin. Note that, a much lesser dose of AZD2014 $(0.204 \mu \mathrm{M})$ than Rapamycin $(6.49 \mu \mathrm{M})$ is also sufficient to exhibit an $\mathrm{IC}_{50}$ in a human CRPCa C4-2 cell line [200]. Moreover, AZD2014 was more potent in the inhibition of 4EBP1 and AKT phosphorylation than Rapamycin [200]. This inhibitor was tested in men with high-risk PCa given prior to radical prostatectomy (NCT02064608). Although completed, there is no published report for the outcome of this clinical trial yet.

Notably, one limitation of dual mTORC1/2 inhibitors is the loss of S6K-mediated negative feedback regulation leading to activation of PI3K signaling via RTK activation [169]. This led to trials with dual PI3K and mTORC1/2 inhibitors.

\subsection{Dual PI3K and mTORC1/2 Inhibitors}

Dual PI3K and mTORC1/2 inhibitors target all four p110 isoforms and both mTOR complexes in order to achieve a more complete blockade of the PI3K-AKT-mTOR signaling axis [11]. In preclinical studies, GDC-0980 and BEZ235 inhibited proliferation of multiple cell lines and induced G1 arrest [201,202]. Moreover, GDC-0980 caused apoptosis in cell lines harboring PIK3CA mutations or PTEN loss, causing direct activation of the PI3K pathway [202]. IC I0 $_{50}$ of GC-0980 with $0.036 \mu \mathrm{M}$ and BEZ235 with $0.038 \mu \mathrm{M}$ have been documented in LNCaP cells, whereas $0.2 \mu \mathrm{M}$ GDC-0980 and $0.06 \mu \mathrm{M}$ BEZ235 are sufficient to exhibit IC 50 in PC3 cells $[202,203]$. Both inhibitors are well tolerated in the clinic with mild side effects, including nausea, vomiting, diarrhea, and fatigue [204-206]. Currently, GDC-0980 in combination with Abiraterone acetate is tested in CRPCa in phase I//II clinical trials (Table 1).

The limited efficacy of monotherapy with PI3K/AKT/mTOR inhibitors is caused by complex reciprocal feedback mechanisms that include the AR and interaction with other signaling pathways. These findings urged towards the need to develop combination therapies.

\subsection{Combination Strategies with PI3K-AKT-mTOR Inhibitors}

The activation of the PI3K-AKT-mTOR pathway is implicated in resistance to chemotherapy, for example, to docetaxel [207]. Mechanistically AKT is activated following chemotherapyinduced double strand breaks. Thus, AKT promotes the survival of cancer cells triggering anti-apoptotic pathways [208-210]. In line with this, inhibition of AKT has been indicated to hypersensitize cells to different chemotherapeutic agents in pre-clinical trials [185,211]. The results are supported by previous xenograft studies, showing that AZD5363 significantly enhances the activity of docetaxel [185]. Moreover, MK-2206 indicated synergistic antitumor efficacy with docetaxel in PC3 xenograft models [183]. 
Since it has been reported that a strong suppression of AR signaling by AR antagonists causes reciprocal activation of PI3K-AKT, dual inhibition with ADT and PI3K, AKT, or mTOR inhibitors may lead to more potent PCa growth inhibition $[118,121]$. In line with this, the combination of Everolimus and Bicalutamide significantly reduced tumor growth rates and tumor volume in LNCaP xenografts compared to Bicalutamide alone [212]. Moreover, this study suggests that combined targeting of AR and mTOR inhibitors can restore sensitivity to anti-androgen therapy. However, clinical results of Everolimus plus Bicalutamide in CRPCa have been contradictory. A phase II study reported low activity of the combination treatment [213]. In contrast, another study showed a response in 18 out of 24 patients (75\%) treated with Everolimus and Bicalutamide [214].

Promising results from a phase I/II study using Ipatasertib in combination with Abiraterone demonstrated improved radiographic progression-free survival (PFS) and overall survival (OS) in patients with CRPCa previously treated with Docetaxel compared to single treatment [215]. Along with these observations, the PI3K inhibitor BEZ235 together with the AR antagonist Enzalutamide resulted in an enhanced apoptosis rate in a PTEN negative PCa [121].

Overall, the clinical application of monotherapy of the PI3K-AKT-mTOR pathway can be limited by drug-resistance, dose-limiting toxicity, and complex reciprocal feedback such as interaction with AR and other signaling pathways [216]. In addition, compensatory mechanism by other factors leading to maintenance of the pathway can also be the reason [217]. Thus, combined application of PI3K-AKT-mTOR inhibitors may have great potential for clinical benefit. Yet, due to complexity of cellular signaling network and unique individual characteristic, stratification of patients and particular biomarkers are needed to improve clinical efficiency of these inhibitors. Current clinically relevant biomarkers include the status of PI3KCA, PI3KCB, or AKT somatic alteration and PTEN loss of PCa patients [218]. However, further identification/characterization of new biomarkers for patient selection in the clinic is still required to enable the development of personalized therapy.

\section{Conclusions}

Several factors within the PI3K-AKT-mTOR signaling have pro-survival activity in PCa cells. These factors can even act individually and independently from each other. Thus, inhibition of one factor within this signaling cascade can lead to a feedback mechanism that results in alternative pro-survival bypass pathways. Therefore, a combinatorial treatment with the goal to inhibit the AR and more than one factor of the PI3K-AKT-mTOR signaling could be beneficial. However, optimally, a patient stratification must precede such a combinatorial therapy with suitable markers to detect which pro-survival factor is being activated in order to use appropriate inhibitors in an individualized manner. This would allow patient-oriented use of a target specific treatment for a personalized therapy.

Author Contributions: T.P. and J.K. wrote, edited, and revised the manuscript. A.B. is a corresponding author. A.B. supervised, provided supports, and revised the manuscript. All authors have read and agreed to the published version of the manuscript.

Funding: This work was supported by the German Academic Exchange Service (DAAD) to T.P.

Institutional Review Board Statement: Not applicable.

Informed Consent Statement: Not applicable.

Conflicts of Interest: The authors declare no conflict of interest.

\section{Abbreviations}

$\begin{array}{ll}\text { ADT } & \text { androgen deprivation therapy; } \\ \text { AML } & \text { acute myeloid leukemia; } \\ \text { AKT/PKB } & \text { protein kinase B; } \\ \text { AR } & \text { androgen receptor; }\end{array}$




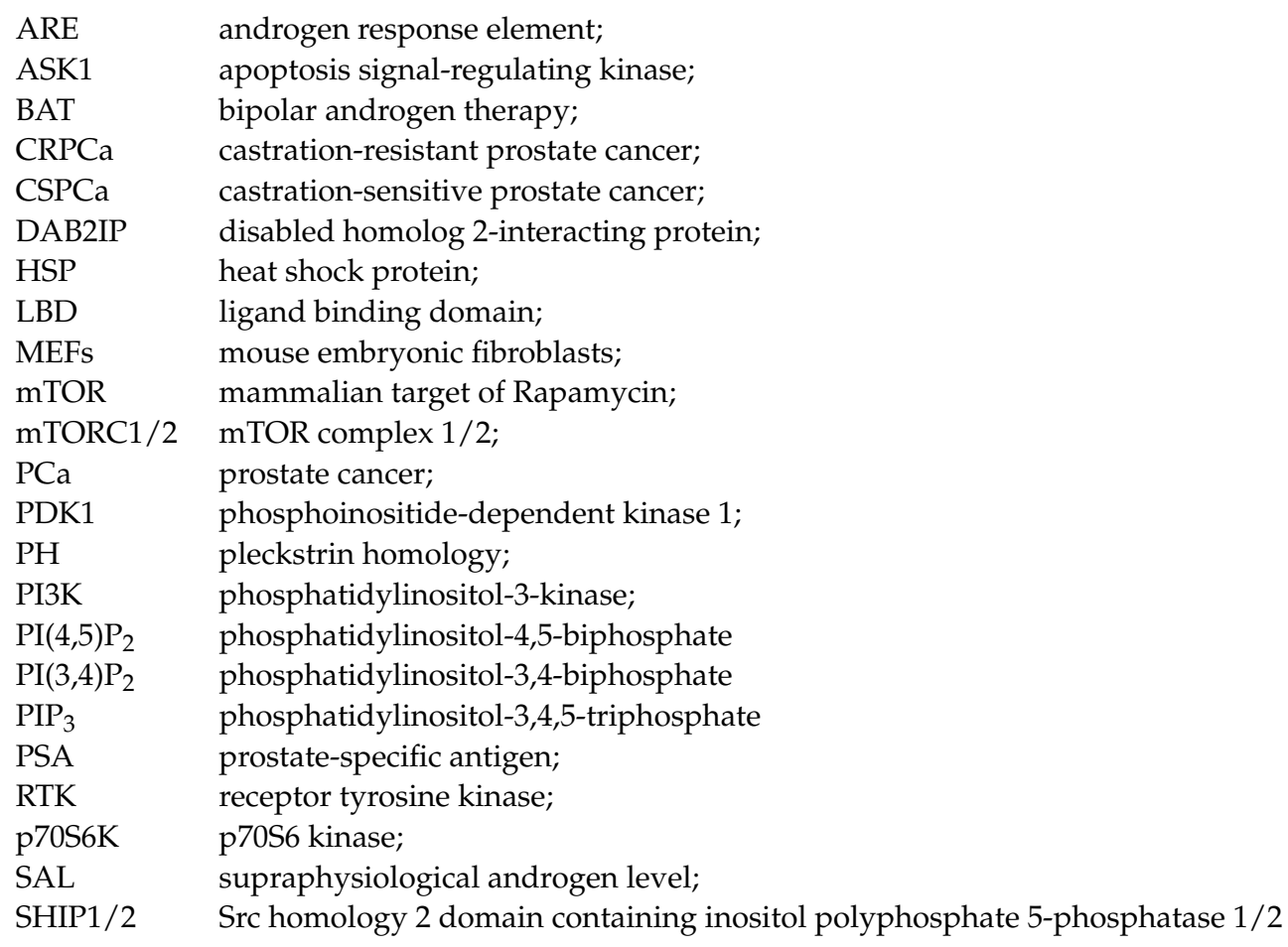

\section{References}

1. Jemal, A.; Siegel, R.; Ward, E.; Murray, T.; Xu, J.; Thun, M.J. Cancer Statistics, 2007. CA Cancer J. Clin. 2007, 57, 43-66. [CrossRef] [PubMed]

2. Siegel, R.L.; Miller, K.D.; Fuchs, H.E.; Jemal, A. Cancer Statistics, 2021. CA Cancer J. Clin. 2021, 71, 7-33. [CrossRef]

3. Rebello, R.J.; Oing, C.; Knudsen, K.E.; Loeb, S.; Johnson, D.C.; Reiter, R.E.; Gillessen, S.; Van der Kwast, T.; Bristow, R.G. Prostate Cancer. Nat. Rev. Dis. Primers 2021, 7, 9. [CrossRef] [PubMed]

4. Lonergan, P.E.; Tindall, D.J. Androgen Receptor Signaling in Prostate Cancer Development and Progression. J. Carcinog. 2011, 10, 20. [PubMed]

5. La Vignera, S.; Condorelli, R.A.; Russo, G.I.; Morgia, G.; Calogero, A.E. Endocrine Control of Benign Prostatic Hyperplasia Andrology 2016, 4, 404-411. [CrossRef] [PubMed]

6. Decker, K.F.; Zheng, D.; He, Y.; Bowman, T.; Edwards, J.R.; Jia, L. Persistent Androgen Receptor-Mediated Transcription in Castration-Resistant Prostate Cancer under Androgen-Deprived Conditions. Nucl. Acids Res. 2012, 40, 10765-10779. [CrossRef] [PubMed]

7. Nelson, P.S. Molecular States Underlying Androgen Receptor Activation: A Framework for Therapeutics Targeting Androgen Signaling in Prostate Cancer. J. Clin. Oncol. 2012, 30, 644-646. [CrossRef] [PubMed]

8. Perner, S.; Cronauer, M.V.; Schrader, A.J.; Klocker, H.; Culig, Z.; Baniahmad, A. Adaptive Responses of Androgen Receptor Signaling in Castration-Resistant Prostate Cancer. Oncotarget 2015, 6, 35542-35555. [CrossRef]

9. Lakshmana, G.; Baniahmad, A. Interference with the Androgen Receptor Protein Stability in Therapy-Resistant Prostate Cancer. Int. J. Cancer 2018, 144, 1775-1779. [CrossRef]

10. Ehsani, M.; David, F.; Baniahmad, A. Androgen Receptor-Dependent Mechanisms Mediating Drug Resistance in Prostate Cancer. Cancers 2021, 13, 1534. [CrossRef] [PubMed]

11. Hsieh, A.C.; Edlind, M.P. PI3K-AKT-mTOR Signaling in Prostate Cancer Progression and Androgen Deprivation Therapy Resistance. Asian J. Androl. 2014, 16, 378-386. [CrossRef] [PubMed]

12. Kim, S.G.; Buel, G.R.; Blenis, J. Nutrient Regulation of the mTOR Complex 1 Signaling Pathway. Mol. Cells 2013, 35, 463-473. [CrossRef]

13. Mori, S.; Nada, S.; Kimura, H.; Tajima, S.; Takahashi, Y.; Kitamura, A.; Oneyama, C.; Okada, M. The mTOR Pathway Controls Cell Proliferation by Regulating the FoxO3a Transcription Factor via SGK1 Kinase. PLoS ONE 2014, 9, e88891. [CrossRef]

14. Castedo, M.; Ferri, K.F.; Kroemer, G. Mammalian Target of Rapamycin (mTOR): Pro- and Anti-apoptotic. Cell Death Differ. 2002, 9, 99-100. [CrossRef] [PubMed]

15. Holroyd, A.K.; Michie, A.M. The Role of mTOR-Mediated Signaling in the Regulation of Cellular Migration. Immunol. Lett. 2018, 196, 74-79. [CrossRef]

16. Jillson, L.; Yette, G.; Laajala, T.; Tilley, W.; Costello, J.; Cramer, S. Androgen Receptor Signaling in Prostate Cancer Genomic Subtypes. Cancers 2021, 13, 3272. [CrossRef] [PubMed]

17. Toren, P.; Zoubeidi, A. Targeting the PI3K/Akt Pathway in Prostate Cancer: Challenges and Opportunities. Int. J. Oncol. 2014, 45, 1793-1801. [CrossRef] [PubMed] 
18. Shorning, B.Y.; Dass, M.S.; Smalley, M.J.; Pearson, H.B. The PI3K-AKT-mTOR Pathway and Prostate Cancer: At the Crossroads of AR, MAPK, and WNT Signaling. Int. J. Mol. Sci. 2020, 21, 4507. [CrossRef] [PubMed]

19. Jia, S.; Liu, Z.; Zhang, S.; Liu, P.; Zhang, L.; Lee, S.H.; Zhang, J.; Signoretti, S.; Loda, M.; Roberts, T.M.; et al. Essential Roles of PI(3)K-p110beta in Cell Growth, Metabolism and Tumorigenesis. Nature 2008, 454, 776-779. [CrossRef]

20. Jiang, X.; Chen, S.; Asara, J.M.; Balk, S.P. Phosphoinositide 3-Kinase Pathway Activation in Phosphate and Tensin Homolog (PTEN)-Deficient Prostate Cancer Cells Is In-Dependent of Receptor Tyrosine Kinases and Mediated by the p110beta and p110delta Catalytic Subunits. J. Biol. Chem. 2010, 285, 14980-14989. [CrossRef] [PubMed]

21. Vanhaesebroeck, B.; Guillermet-Guibert, J.; Graupera, M.; Bilanges, B. The Emerging Mechanisms of Isoform-Specific PI3K Signalling. Nat. Rev. Mol. Cell Biol. 2010, 11, 329-341. [CrossRef]

22. Thorpe, L.; Yuzugullu, H.; Zhao, J.J. PI3K in Cancer: Divergent Roles of Isoforms, Modes of Activation and Therapeutic Targeting. Nat. Rev. Cancer 2014, 15, 7-24. [CrossRef]

23. Liu, P.; Cheng, H.; Roberts, T.M.; Zhao, J.J. Targeting the Phosphoinositide 3-Kinase Pathway in Cancer. Nat. Rev. Drug Discov. 2009, 8, 627-644. [CrossRef]

24. Guillermet-Guibert, J.; Bjorklof, K.; Salpekar, A.; Gonella, C.; Ramadani, F.; Bilancio, A.; Meek, S.; Smith, A.J.; Okkenhaug, K.; Vanhaesebroeck, B. The p110beta Isoform of Phosphoinositide 3-Kinase Signals Downstream of G Protein-Coupled Receptors and Is Functionally Redundant with p110gamma. Proc. Natl. Acad. Sci. USA 2008, 105, 8292-8297. [CrossRef]

25. Gewinner, C.; Wang, Z.C.; Richardson, A.; Teruya-Feldstein, J.; Etemadmoghadam, D.; Bowtell, D.; Barretina, J.; Lin, W.M.; Rameh, L.; Salmena, L.; et al. Evidence that Inositol Polyphosphate 4-Phosphatase Type II Is a Tumor Suppressor that Inhibits PI3K Signaling. Cancer Cell 2009, 16, 115-125. [CrossRef] [PubMed]

26. Lemmon, M.A. Pleckstrin Homology (PH) Domains and Phosphoinositides. Biochem. Soc. Symp. 2007, 74, 81-93. [CrossRef] [PubMed]

27. Papa, A.; Pandolfi, P.P. The PTEN-PI3K Axis in Cancer. Biomolecules 2019, 9, 153. [CrossRef]

28. Malek, M.; Kielkowska, A.; Chessa, T.; Anderson, K.E.; Barneda, D.; Pir, P.; Nakanishi, H.; Eguchi, S.; Koizumi, A.; Sasaki, J.; et al. PTEN Regulates PI(3,4)P 2 Signaling Downstream of Class I PI3K. Mol. Cell 2017, 68, 566-580. [CrossRef] [PubMed]

29. Phin, S.; Moore, M.W.; Cotter, P.D. Genomic Rearrangements of PTEN in Prostate Cancer. Front. Oncol. 2013, 3, 240. [CrossRef]

30. Hodgson, M.C.; Shao, L.-J.; Frolov, A.; Li, R.; Peterson, L.E.; Ayala, G.; Ittmann, M.M.; Weigel, N.L.; Agoulnik, I.U. Decreased Expression and Androgen Regulation of the Tumor Suppressor Gene INPP4B in Prostate Cancer. Cancer Res. $2011,71,572-582$. [CrossRef] [PubMed]

31. Faes, S.; Dormond, O. PI3K and AKT: Unfaithful Partners in Cancer. Int. J. Mol. Sci. 2015, 16, 21138-21152. [CrossRef] [PubMed]

32. Majumder, P.K.; Yeh, J.J.; George, D.J.; Febbo, P.G.; Kum, J.; Xue, Q.; Bikoff, R.; Ma, H.; Kantoff, P.; Golub, T.R.; et al. Prostate Intraepithelial Neoplasia Induced by Prostate Restricted Akt Activation: The MPAKT Model. Proc. Natl. Acad. Sci. USA 2003, 100, 7841-7846. [CrossRef] [PubMed]

33. Drake, J.M.; Graham, N.A.; Lee, J.K.; Stoyanova, T.; Faltermeier, C.M.; Sud, S.; Titz, B.; Huang, J.; Pienta, K.J.; Graeber, T.G.; et al. Metastatic Castration-Resistant Prostate Cancer Reveals Intrapatient Similarity and Interpatient Heterogeneity of Therapeutic Kinase Targets. Proc. Natl. Acad. Sci. USA 2013, 110, 4762-4769. [CrossRef]

34. Balasuriya, N.; Kunkel, M.T.; Liu, X.; Biggar, K.K.; Li, S.S.; Newton, A.C.; O’Donoghue, P. Genetic Code Expansion and Live Cell Imaging Reveal That Thr-308 Phosphorylation Is Irreplaceable and Sufficient for Akt1 Activity. J. Biol. Chem. 2018, 293, 10744-10756. [CrossRef]

35. Balasuriya, N.; Davey, N.E.; Johnson, J.L.; Liu, H.; Biggar, K.K.; Cantley, L.C.; Li, S.S.-C.; O’Donoghue, P. PhosphorylationDependent Substrate Selectivity of Protein Kinase B (AKT1). J. Biol. Chem. 2020, 295, 8120-8134. [CrossRef] [PubMed]

36. Manning, B.D.; Toker, A. AKT/PKB Signaling: Navigating the Network. Cell 2017, 169, 381-405. [CrossRef]

37. Kremer, C.L.; Klein, R.R.; Mendelson, J.; Browne, W.; Samadzedeh, L.K.; Vanpatten, K.; Highstrom, L.; Pestano, G.A.; Nagle, R.B. Expression of mTOR Signaling Pathway Markers in Prostate Cancer Progression. Prostate 2006, 66, 1203-1212. [CrossRef]

38. Laplante, M.; Sabatini, D.M. mTOR Signaling in Growth Control and Disease. Cell 2012, 149, 274-293. [CrossRef]

39. Sancak, Y.; Thoreen, C.C.; Peterson, T.R.; Lindquist, R.A.; Kang, S.A.; Spooner, E.; Carr, S.A.; Sabatini, D.M. PRAS40 Is an Insulin-Regulated Inhibitor of the mTORC1 Protein Kinase. Mol. Cell 2007, 25, 903-915. [CrossRef]

40. Haar, E.V.; Lee, S.-I.; Bandhakavi, S.; Griffin, T.; Kim, D.-H. Insulin Signalling to mTOR Mediated by the Akt/PKB Substrate PRAS40. Nature 2007, 9, 316-323. [CrossRef]

41. Oshiro, N.; Takahashi, R.; Yoshino, K.-I.; Tanimura, K.; Nakashima, A.; Eguchi, S.; Miyamoto, T.; Hara, K.; Takehana, K.; Avruch, J.; et al. The Proline-rich Akt Substrate of $40 \mathrm{kDa}$ (PRAS40) Is a Physiological Substrate of Mammalian Target of Rapamycin Complex 1. J. Biol. Chem. 2007, 282, 20329-20339. [CrossRef] [PubMed]

42. Inoki, K.; Zhu, T.; Guan, K.-L. TSC2 Mediates Cellular Energy Response to Control Cell Growth and Survival. Cell 2003, 115, 577-590. [CrossRef]

43. Inoki, K.; Ouyang, H.; Zhu, T.; Lindvall, C.; Wang, Y.; Zhang, X.; Yang, Q.; Bennett, C.; Harada, Y.; Stankunas, K.; et al. TSC2 Integrates Wnt and Energy Signals via a Coordinated Phosphorylation by AMPK and GSK3 to Regulate Cell Growth. Cell 2006, 126, 955-968. [CrossRef] [PubMed]

44. Brown, E.J.; Beal, P.A.; Keith, C.T.; Chen, J.; Shin, T.B.; Schreiber, S.L. Control of p70 S6 Kinase by Kinase Activity of FRAP In Vivo. Nature 1995, 377, 441-446. [CrossRef] 
45. Gingras, A.-C.; Kennedy, S.; O’Leary, M.A.; Sonenberg, N.; Hay, N. 4E-BP1, A Repressor of mRNA Translation, Is Phosphorylated and Inactivated by the Akt (PKB) Signaling Pathway. Genes Dev. 1998, 12, 502-513. [CrossRef]

46. Jung, C.H.; Jun, C.B.; Ro, S.-H.; Kim, Y.-M.; Otto, N.M.; Cao, J.; Kundu, M.; Kim, D.-H. ULK-Atg13-FIP200 Complexes Mediate mTOR Signaling to the Autophagy Machinery. Mol. Biol. Cell 2009, 20, 1992-2003. [CrossRef]

47. Hosokawa, N.; Hara, T.; Kaizuka, T.; Kishi, C.; Takamura, A.; Miura, Y.; Iemura, S.-I.; Natsume, T.; Takehana, K.; Yamada, N.; et al. Nutrient-dependent mTORC1 Association with the ULK1-Atg13-FIP200 Complex Required for Autophagy. Mol. Biol. Cell 2009, 20, 1981-1991. [CrossRef]

48. Ganley, I.G.; Lam du, H.; Wang, J.; Ding, X.; Chen, S.; Jiang, X. ULK1.ATG13.FIP200 Complex Mediates mTOR Signaling and Is Essential for Autophagy. J. Biol. Chem. 2009, 284, 12297-12305. [CrossRef]

49. Fu, W.; Hall, M.N. Regulation of mTORC2 Signaling. Genes 2020, 11, 1045. [CrossRef]

50. Huang, J.; Dibble, C.C.; Matsuzaki, M.; Manning, B.D. The TSC1-TSC2 Complex Is Required for Proper Activation of mTOR Complex 2. Mol. Cell. Biol. 2008, 28, 4104-4115. [CrossRef]

51. Huang, J.; Wu, S.; Wu, C.-L.; Manning, B.D. Signaling Events Downstream of Mammalian Target of Rapamycin Complex 2 Are Attenuated in Cells and Tumors Deficient for the Tuberous Sclerosis Complex Tumor Suppressors. Cancer Res. 2009, 69, 6107-6114. [CrossRef] [PubMed]

52. Dibble, C.C.; Asara, J.M.; Manning, B.D. Characterization of Rictor Phosphorylation Sites Reveals Direct Regulation of mTOR Complex 2 by S6K1. Mol. Cell. Biol. 2009, 29, 5657-5670. [CrossRef] [PubMed]

53. Julien, L.-A.; Carrière, A.; Moreau, J.; Roux, P.P. mTORC1-Activated S6K1 Phosphorylates Rictor on Threonine 1135 and Regulates mTORC2 Signaling. Mol. Cell. Biol. 2010, 30, 908-921. [CrossRef] [PubMed]

54. Sarbassov, D.D.; Guertin, D.A.; Ali, S.M.; Sabatini, D.M. Phosphorylation and Regulation of Akt/PKB by the Rictor-mTOR Complex. Science 2005, 307, 1098-1101. [CrossRef] [PubMed]

55. Guertin, D.A.; Stevens, D.M.; Saitoh, M.; Kinkel, S.; Crosby, K.; Sheen, J.-H.; Mullholland, D.J.; Magnuson, M.; Wu, H.; Sabatini, D.M. mTOR Complex 2 Is Required for the Development of Prostate Cancer Induced by Pten Loss in Mice. Cancer Cell 2009, 15, 148-159. [CrossRef]

56. Ellwood-Yen, K.; Keilhack, H.; Kunii, K.; Dolinski, B.; Connor, Y.; Hu, K.; Nagashima, K.; O’Hare, E.; Erkul, Y.; Di Bacco, A.; et al. PDK1 Attenuation Fails to Prevent Tumor Formation in PTEN-Deficient Transgenic Mouse Models. Cancer Res. 2011, 71, 3052-3065. [CrossRef]

57. Malik, S.N.; Brattain, M.; Ghosh, P.M.; Troyer, D.A.; Prihoda, T.; Bedolla, R.; Kreisberg, J.I. Immunohisto-Chemical Demonstration of Phospho-Akt in High Gleason Grade Prostate Cancer. Clin. Cancer Res. 2002, 8, 1168-1171.

58. Liao, Y.; Grobholz, R.; Abel, U.; Trojan, L.; Michel, M.S.; Angel, P.; Mayer, D. Increase of AKT/PKB Expression Correlates with Gleason Pattern in Human Prostate Cancer. Int. J. Cancer 2003, 107, 676-680. [CrossRef]

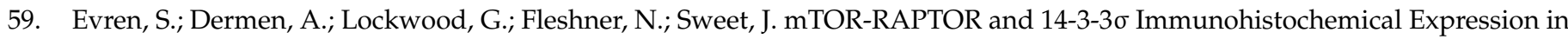
High Grade Prostatic Intraepithelial Neoplasia and Prostatic Adenocarcinomas: A Tissue Microarray Study. J. Clin. Pathol. 2011, 64, 683-688. [CrossRef]

60. Sutherland, S.I.; Pe Benito, R.; Henshall, S.M.; Horvath, L.G.; Kench, J.G. Expression of Phosphorylated-mTOR during the Development of Prostate Cancer. Prostate 2014, 74, 1231-1239. [CrossRef]

61. Saranyutanon, S.; Srivastava, S.K.; Pai, S.; Singh, S.; Singh, A.P. Therapies Targeted to Androgen Receptor Signaling Axis in Prostate Cancer: Progress, Challenges, and Hope. Cancers 2019, 12, 51. [CrossRef]

62. Liao, R.S.; Ma, S.; Miao, L.; Li, R.; Yin, Y.; Raj, G.V. Androgen Receptor-Mediated Non-Genomic Regulation of Prostate Cancer Cell Proliferation. Transl. Androl. Urol. 2013, 2, 187-196.

63. Wilson, S.; Qi, J.; Filipp, F.V. Refinement of the Androgen Response Element Based on ChIP-Seq in Andro-Gen-Insensitive and Androgen-Responsive Prostate Cancer Cell Lines. Sci. Rep. 2016, 6, 32611. [CrossRef] [PubMed]

64. He, Y.; Wei, T.; Ye, Z.; Orme, J.J.; Lin, D.; Sheng, H.; Fazli, L.; Karnes, R.J.; Jimenez, R.; Wang, L.; et al. A Noncanonical AR Addiction Drives Enzalutamide Resistance in Prostate Cancer. Nat. Commun. 2021, 12, 1-14.

65. Ueda, T.; Bruchovsky, N.; Sadar, M. Activation of the Androgen Receptor N-terminal Domain by Interleukin-6 via MAPK and STAT3 Signal Transduction Pathways. J. Biol. Chem. 2002, 277, 7076-7085. [CrossRef]

66. Traish, A.M.; Morgentaler, A. Epidermal Growth Factor Receptor Expression Escapes Androgen Regulation in Prostate Cancer: A Potential Molecular Switch for Tumour Growth. Br. J. Cancer 2009, 101, 1949-1956. [CrossRef]

67. Culig, Z.; Hobisch, A.; Cronauer, M.V.; Radmayr, C.; Trapman, J.; Hittmair, A.; Bartsch, G.; Klocker, H. Androgen Receptor Activation in Prostatic Tumor Cell Lines by Insulin-Like Growth Factor-I, Keratinocyte Growth Factor, and EP-Idermal Growth Factor. Cancer Res. 1994, 54, 5474-5478. [PubMed]

68. Wen, S.; Niu, Y.; Huang, H. Posttranslational Regulation of Androgen Dependent and Independent Androgen Receptor Activities in Prostate Cancer. Asian J. Urol. 2019, 7, 203-218. [CrossRef]

69. Peterziel, H.; Mink, S.; Schonert, A.; Becker, M.; Klocker, H.; Cato, A. Rapid Signalling by Androgen Receptor in Prostate Cancer Cells. Oncogene 1999, 18, 6322-6329. [CrossRef]

70. Leung, J.; Sadar, M.D. Non-Genomic Actions of the Androgen Receptor in Prostate Cancer. Front. Endocrinol. 2017, 8, 2. [CrossRef] [PubMed] 
71. Migliaccio, A.; Castoria, G.; Di Domenico, M.; De Falco, A.; Bilancio, A.; Lombardi, M.; Barone, M.V.; Ametrano, D.; Zannini, M.S.; Abbondanza, C.; et al. Steroid-Induced Androgen Receptor-Oestradiol Receptor Beta-Src Complex Triggers Prostate Cancer Cell Proliferation. EMBO J. 2000, 19, 5406-5417. [CrossRef] [PubMed]

72. Heinlein, C.A.; Chang, C. The Roles of Androgen Receptors and Androgen-Binding Proteins in Nongenomic Androgen Actions. Mol. Endocrinol. 2002, 16, 2181-2187. [CrossRef]

73. Baron, S.; Manin, M.; Beaudoin, C.; Leotoing, L.; Communal, Y.; Veyssiere, G.; Morel, L. Androgen Receptor Mediates Nongenomic Activation of Phosphatidylinositol 3-OH Kinase in Androgen-Sensitive Epithelial Cells. J. Biol. Chem. 2004, 279, 14579-14586. [CrossRef] [PubMed]

74. Gatson, J.W.; Kaur, P.; Singh, M. Dihydrotestosterone Differentially Modulates the Mitogen-Activated Protein Kinase and the Phosphoinositide 3-Kinase/Akt Pathways through the Nuclear and Novel Membrane Androgen Receptor in C6 Cells. Endocrinology 2006, 147, 2028-2034. [CrossRef]

75. Cinar, B.; Mukhopadhyay, N.K.; Meng, G.; Freeman, M.R. Phosphoinositide 3-Kinase-independent Non-genomic Signals Transit from the Androgen Receptor to Akt1 in Membrane Raft Microdomains. J. Biol. Chem. 2007, 282, 29584-29593. [CrossRef] [PubMed]

76. Kokal, M.; Mirzakhani, K.; Pungsrinont, T.; Baniahmad, A. Mechanisms of Androgen Receptor Agonist- and Antagonist-Mediated Cellular Senescence in Prostate Cancer. Cancers 2020, 12, 1833. [CrossRef] [PubMed]

77. Roediger, J.; Hessenkemper, W.; Bartsch, S.; Manvelyan, M.; Huettner, S.S.; Liehr, T.; Esmaeili, M.; Foller, S.; Petersen, I.; Grimm, M.-O.; et al. Supraphysiological Androgen Levels Induce Cellular Senescence in Human Prostate Cancer Cells through the Src-Akt Pathway. Mol. Cancer 2014, 13, 214. [CrossRef] [PubMed]

78. Pungsrinont, T.; Sutter, M.F.; Ertingshausen, M.C.C.M.; Lakshmana, G.; Kokal, M.; Khan, A.S.; Baniahmad, A. Senolytic Compounds Control a Distinct Fate of Androgen Receptor Agonist- and Antagonist-Induced Cellular Senescent LNCaP Prostate Cancer Cells. Cell Biosci. 2020, 10, 59. [CrossRef]

79. Wen, Y.; Hu, M.C.; Makino, K.; Spohn, B.; Bartholomeusz, G.; Yan, D.H.; Hung, M.C. HER-2/Neu Promotes AndrogenIndependent Survival and Growth of Prostate Cancer Cells through the Akt Pathway. Cancer Res. 2000, 60, 6841-6845. [PubMed]

80. Koryakina, Y.; Ta, H.Q.; Gioeli, D. Androgen Receptor Phosphorylation: Biological Context and Functional Consequences. Endocr. Relat. Cancer 2014, 21, 131-145. [CrossRef] [PubMed]

81. Brawley, S.; Mohan, R.; Nein, C.D. Localized Prostate Cancer: Treatment Options. Am. Fam. Phys. 2018, 97, 798-805.

82. Huggins, C.; Hodges, C.V. Studies on Prostatic Cancer: I. the Effect of Castration, of Estrogen and of Androgen Injection on Serum Phosphatases in Meta-Static Carcinoma of the Prostate. Cancer Res. 1941, 1, 293-297.

83. Sharifi, N.; Gulley, J.L.; Dahut, W.L. Androgen Deprivation Therapy for Prostate Cancer. JAMA 2005, 294, 238-244. [CrossRef] [PubMed]

84. Harris, W.P.; Mostaghel, E.A.; Nelson, P.S.; Montgomery, B. Androgen Deprivation Therapy: Progress in Understanding Mechanisms of Resistance and Optimizing Androgen Depletion. Nat. Clin. Pract. Urol. 2009, 6, 76-85. [CrossRef] [PubMed]

85. Mills, I. Maintaining and Reprogramming Genomic Androgen Receptor Activity in Prostate Cancer. Nat. Rev. Cancer 2014, 14, 187-198. [CrossRef] [PubMed]

86. Del Re, M.; Crucitta, S.; Restante, G.; Rofi, E.; Arrigoni, E.; Biasco, E.; Sbrana, A.; Coppi, E.; Galli, L.; Bracarda, S.; et al. Pharmacogenetics of Androgen Signaling in Prostate Cancer: Focus on Castration Resistance and Predictive Biomarkers of Response to Treatment. Crit. Rev. Oncol. Hematol. 2018, 125, 51-59. [CrossRef] [PubMed]

87. Xin, L.; Teitell, M.A.; Lawson, D.A.; Kwon, A.; Mellinghoff, I.K.; Witte, O.N. Progression of Prostate Cancer by Synergy of AKT with Genotropic and Nongenotropic Actions of the Androgen Receptor. Proc. Natl. Acad. Sci. USA 2006, 103, 7789-7794. [CrossRef] [PubMed]

88. Helsen, C.; Broeck, T.V.D.; Voet, A.; Prekovic, S.; Van Poppel, H.; Joniau, S.; Claessens, F. Androgen Receptor Antagonists for Prostate Cancer Therapy. Endocr. Relat. Cancer 2014, 21, 105-118. [CrossRef] [PubMed]

89. Maylin, Z.R.; Nicolescu, R.C.; Pandha, H.; Asim, M. Breaking Androgen Receptor Addiction of Prostate Cancer by Targeting Different Functional Domains in the Treatment of Advanced Disease. Transl. Oncol. 2021, 14, 101115. [CrossRef]

90. Denmeade, S.R.; Isaacs, J.T. Bipolar Androgen Therapy: The Rationale for Rapid Cycling of Supraphysiologic Androgen/Ablation in Men with Castration Resistant Prostate Cancer. Prostate 2010, 70, 1600-1607. [CrossRef]

91. Szmulewitz, R.; Mohile, S.; Posadas, E.; Kunnavakkam, R.; Karrison, T.; Manchen, E.; Stadler, W.M. A Randomized Phase 1 Study of Testosterone Replacement for Patients with Low-Risk Castration-Resistant Prostate Cancer. Eur. Urol. 2009, 56, 97-103. [CrossRef] [PubMed]

92. Morris, M.J.; Huang, D.; Kelly, W.K.; Slovin, S.F.; Stephenson, R.D.; Eicher, C.; De La Cruz, A.; Curley, T.; Schwartz, L.H.; Scher, H.I. Phase 1 Trial of High-Dose Exogenous Testosterone in Patients with Castration-Resistant Metastatic Prostate Cancer. Eur. Urol. 2009, 56, 237-244. [CrossRef] [PubMed]

93. Leone, G.; Buttigliero, C.; Pisano, C.; Di Stefano, R.F.; Tabbò, F.; Turco, F.; Vignani, F.; Scagliotti, G.V.; Di Maio, M.; Tucci, M. Bipolar Androgen Therapy in Prostate Cancer: Current Evidences and Future Perspectives. Crit. Rev. Oncol. 2020, $152,102994$. [CrossRef]

94. Schweizer, M.T.; Wang, H.; Luber, B.; Nadal, R.; Spitz, A.; Rosen, D.M.; Cao, H.; Antonarakis, E.S.; Eisenberger, M.A.; Carducci, M.A.; et al. Bipolar Androgen Therapy for Men with Androgen Ablation Naïve Prostate Cancer: Results from the Phase II BATMAN Study. Prostate 2016, 76, 1218-1226. [CrossRef] [PubMed] 
95. Teply, B.A.; Wang, H.; Luber, B.; Sullivan, R.; Rifkind, I.; Bruns, A.; Spitz, A.; DeCarli, M.; Sinibaldi, V.; Pratz, C.F.; et al. Bipolar Androgen Therapy in Men with Metastatic Castration-Resistant Prostate Cancer after Progression on Enzalutamide: An Open-Label, Phase 2, Multicohort Study. Lancet Oncol. 2017, 19, 76-86. [CrossRef]

96. Denmeade, S.R. Bipolar Androgen Therapy in the Treatment of Prostate Cancer. Clin. Adv. Hematol. Oncol. 2018, 16, 408-411. [PubMed]

97. Wach, S.; Taubert, H.; Cronauer, M. Role of Androgen Receptor Splice Variants, Their Clinical Relevance and Treatment Options. World J. Urol. 2019, 38, 647-656. [CrossRef]

98. Fine, S.W. Neuroendocrine Tumors of the Prostate. Mod. Pathol. 2018, 31, 122-132. [CrossRef] [PubMed]

99. Huang, Y.-H.; Zhang, Y.-Q.; Huang, J.-T. Neuroendocrine Cells of Prostate Cancer: Biologic Functions and Molecular Mechanisms. Asian J. Androl. 2019, 21, 291-295. [CrossRef] [PubMed]

100. Puca, L.; Vlachostergios, P.; Beltran, H. Neuroendocrine Differentiation in Prostate Cancer: Emerging Biology, Models, and Therapies. Cold Spring Harb. Perspect. Med. 2018, 9, a030593. [CrossRef] [PubMed]

101. Shiota, M.; Fujimoto, N.; Kashiwagi, E.; Eto, M. The Role of Nuclear Receptors in Prostate Cancer. Cells 2019, 8, 602. [CrossRef]

102. Puhr, M.; Hoefer, J.; Eigentler, A.; Ploner, C.; Handle, F.; Schaefer, G.; Kroon, J.; Leo, A.; Heidegger, I.M.; Eder, E.I.; et al. The Glucocorticoid Receptor Is a Key Player for Prostate Cancer Cell Survival and a Target for Improved Antiandrogen Therapy. Clin. Cancer Res. 2017, 24, 927-938. [CrossRef]

103. Grindstad, T.; Andersen, S.; Al-Saad, S.; Donnem, T.; Kiselev, Y.; Nordahl Melbø-Jørgensen, C.; Skjefstad, K.; Busund, L.T.; Bremnes, R.M.; Richardsen, E. High Progesterone Receptor Expression in Prostate Cancer Is Associated with Clinical Failure. PLoS ONE 2015, 10, e0116691. [CrossRef] [PubMed]

104. Nelson, E.C.; Cambio, A.J.; Yang, J.C.; Ok, J.H.; Lara, P.N., Jr.; Evans, C.P. Clinical Implications of Neuroendocrine Differentiation in Prostate Cancer. Prostate Cancer Prost. Dis. 2007, 10, 6-14. [CrossRef] [PubMed]

105. Bland, T.; Wang, J.; Yin, L.; Pu, T.; Li, J.; Gao, J.; Lin, T.-P.; Gao, A.C.; Wu, B.J. WLS-Wnt Signaling Promotes Neuroendocrine Prostate Cancer. iScience 2020, 24, 101970. [CrossRef] [PubMed]

106. Nevedomskaya, E.; Baumgart, S.J.; Haendler, B. Recent Advances in Prostate Cancer Treatment and Drug Discovery. Int. J. Mol. Sci. 2018, 19, 1359. [CrossRef] [PubMed]

107. Sumanasuriya, S.; De Bono, J. Treatment of Advanced Prostate Cancer-A Review of Current Therapies and Future Promise. Cold Spring Harb. Perspect. Med. 2017, 8, a030635. [CrossRef] [PubMed]

108. Taylor, B.S.; Schultz, N.; Hieronymus, H.; Gopalan, A.; Xiao, Y.; Carver, B.S.; Arora, V.K.; Kaushik, P.; Cerami, E.; Reva, B.; et al. Integrative Genomic Profiling of Human Prostate Cancer. Cancer Cell 2010, 18, 11-22. [CrossRef] [PubMed]

109. Robinson, D.; Van Allen, E.M.; Wu, Y.-M.; Schultz, N.; Lonigro, R.J.; Mosquera, J.-M.; Montgomery, B.; Taplin, M.-E.; Pritchard, C.C.; Attard, G.; et al. Integrative Clinical Genomics of Advanced Prostate Cancer. Cell 2015, 161, 1215-1228. [CrossRef]

110. Abida, W.; Cyrta, J.; Heller, G.; Prandi, D.; Armenia, J.; Coleman, I.; Cieslik, M.; Benelli, M.; Robinson, D.; Van Allen, E.M.; et al. Genomic Correlates of Clinical Outcome in Advanced Prostate Cancer. Proc. Natl. Acad. Sci. USA 2019, 116, 11428-11436. [CrossRef]

111. Wang, Y.; Kreisberg, J.I.; Ghosh, P.M. Cross-Talk between the Androgen Receptor and the Phosphatidylinositol 3-Kinase/Akt Pathway in Prostate Cancer. Curr. Cancer Drug Targets 2007, 7, 591-604. [CrossRef] [PubMed]

112. McMenamin, M.E.; Soung, P.; Perera, S.; Kaplan, I.; Loda, M.; Sellers, W.R. Loss of PTEN Expression in Paraffin-Embedded Primary Prostate Cancer Correlates with High Gleason Score and Advanced Stage. Cancer Res. 1999, 59, 4291-4296. [PubMed]

113. Geybels, M.S.; Fang, M.; Wright, J.L.; Qu, X.; Bibikova, M.; Klotzle, B.; Fan, J.-B.; Feng, Z.; Ostrander, E.A.; Nelson, P.S.; et al. PTEN Loss Is Associated with Prostate Cancer Recurrence and Alterations in Tumor DNA Methylation Profiles. Oncotarget 2017, 8, 84338-84348. [CrossRef]

114. Pearson, H.B.; Li, J.; Meniel, V.S.; Fennell, C.M.; Waring, P.; Montgomery, K.G.; Rebello, R.J.; Macpherson, A.A.; Koushyar, S.; Furic, L.; et al. Identification of Pik3ca Mutation as a Genetic Driver of Prostate Cancer That Cooperates with Pten Loss to Accelerate Progression and Castration-Resistant Growth. Cancer Discov. 2018, 8, 764-779. [CrossRef] [PubMed]

115. Jamaspishvili, T.; Berman, D.; Ross, A.E.; Scher, H.I.; De Marzo, A.M.; Squire, J.; Lotan, T.L. Clinical Implications of PTEN Loss in Prostate Cancer. Nat. Rev. Urol. 2018, 15, 222-234. [CrossRef] [PubMed]

116. Wang, S.; Gao, J.; Lei, Q.-Y.; Rozengurt, N.; Pritchard, C.; Jiao, J.; Thomas, G.; Li, G.; Roy-Burman, P.; Nelson, P.S.; et al. ProstateSpecific Deletion of the Murine Pten Tumor Suppressor Gene Leads to Metastatic Prostate Cancer. Cancer Cell 2003, 4, $209-221$. [CrossRef]

117. Sarker, D.; Reid, A.H.; Yap, T.A.; de Bono, J.S. Targeting the PI3K/AKT Pathway for the Treatment of Prostate Cancer. Clin. Cancer Res. 2009, 15, 4799-4805. [CrossRef]

118. Mulholland, D.J.; Tran, L.M.; Li, Y.; Cai, H.; Morim, A.; Wang, S.; Plaisier, S.; Garraway, I.P.; Huang, J.; Graeber, T.; et al. Cell Autonomous Role of PTEN in Regulating Castration-Resistant Prostate Cancer Growth. Cancer Cell 2011, 19, 792-804. [CrossRef] [PubMed]

119. Mulholland, D.J.; Kobayashi, N.; Ruscetti, M.; Zhi, A.; Tran, L.M.; Huang, J.; Gleave, M.; Wu, H. Pten Loss and RAS/MAPK Activation Cooperate to Promote EMT and Metastasis Initiated from Prostate Cancer Stem/Progenitor Cells. Cancer Res. 2012, 72, 1878-1889. [CrossRef] [PubMed] 
120. Kwak, M.K.; Johnson, D.T.; Zhu, C.; Lee, S.H.; Ye, D.-W.; Luong, R.; Sun, Z. Conditional Deletion of the Pten Gene in the Mouse Prostate Induces Prostatic Intraepithelial Neoplasms at Early Ages but a Slow Progression to Prostate Tumors. PLoS ONE 2013, 8 , e53476. [CrossRef] [PubMed]

121. Carver, B.S.; Chapinski, C.; Wongvipat, J.; Hieronymus, H.; Chen, Y.; Chandarlapaty, S.; Arora, V.K.; Le, C.; Koutcher, J.; Scher, H.; et al. Reciprocal Feedback Regulation of PI3K and Androgen Receptor Signaling in PTEN-Deficient Prostate Cancer. Cancer Cell 2011, 19, 575-586. [CrossRef]

122. Jessen, K.; Kessler, L.; Kucharski, J.; Guo, X.; Staunton, J.; Janes, M.; Elia, M.; Banerjee, U.; Lan, L.; Wang, S.; et al. Abstract A171: A Potent and Selective PI3K Inhibitor, INK1117, Targets Human Cancers Harboring Oncogenic PIK3CA Mutations. Mol. Cancer Ther. 2011, 10, 171.

123. Fritsch, C.M.; Schnell, C.; Chatenay-Rivauday, C.; Guthy, D.A.; De Pover, A.; Wartmann, M.; Brachmann, S.; Maira, S.M.; Huang, A.; Quadt, C.; et al. NVP-BYL719, a Novel PI3Kalpha Selective In-Hibitor with All the Characteristics Required for Clinical Development as an Anti-Cancer Agent. Cancer Res. 2012, 72. [CrossRef]

124. Juric, D.; Rodon, J.; Tabernero, J.; Janku, F.; Burris, H.A.; Schellens, J.H.; Middleton, M.R.; Berlin, J.; Schuler, M.; Gil-Martin, M.; et al. Phosphatidylinositol 3-Kinase $\alpha$-Selective Inhibition with Alpelisib (BYL719) in PIK3CA-Altered Solid Tumors: Results from the First-in-Human Study. J. Clin. Oncol. 2018, 36, 1291-1299. [CrossRef] [PubMed]

125. Tzenaki, N.; Andreou, M.; Stratigi, K.; Vergetaki, A.; Makrigiannakis, A.; Vanhaesebroeck, B.; Papakonstanti, E.A. High Levels of p1108 PI3K Expression in Solid Tumor Cells Suppress PTEN Activity, Generating Cellular Sensitivity to p1108 Inhibitors through PTEN Activation. FASEB J. 2012, 26, 2498-2508. [CrossRef] [PubMed]

126. Zhu, Q.; Youn, H.; Tang, J.; Tawfik, O.; Dennis, K.; Terranova, P.F.; Du, J.; Raynal, P.; Thrasher, J.B.; Li, B. Phosphoinositide 3-OH Kinase p85alpha and p110beta Are Essential for Androgen Receptor Transactivation and Tumor Progression in Prostate Cancers. Oncogene 2008, 27, 4569-4579. [CrossRef] [PubMed]

127. Li, B.; Sun, A.; Youn, H.; Hong, Y.; Terranova, P.F.; Thrasher, J.; Xu, P.; Spencer, D. Conditional Akt Activation Promotes Androgen-Independent Progression of Prostate Cancer. Carcinogenesis 2006, 28, 572-583. [CrossRef] [PubMed]

128. Chen, M.; Pratt, C.; Zeeman, M.E.; Schultz, N.; Taylor, B.S.; O’Neill, A.; Castillo-Martin, M.; Nowak, D.G.; Naguib, A.; Grace, D.M.; et al. Identification of PHLPP1 as a Tumor Suppressor Reveals the Role of Feedback Activation in PTEN-Mutant Prostate Cancer Progression. Cancer Cell 2011, 20, 173-186. [CrossRef] [PubMed]

129. Pandey, P.; Seshacharyulu, P.; Das, S.; Rachagani, S.; Ponnusamy, M.P.; Yan, Y.; Johansson, S.L.; Datta, K.; Lin, M.F.; Batra, S.K. Impaired Expression of Protein Phosphatase 2A Subunits Enhances Metastatic Potential of Human Prostate Cancer Cells through Activation of AKT Pathway. Br. J. Cancer 2013, 108, 2590-2600. [CrossRef] [PubMed]

130. Pei, H.; Li, L.; Fridley, B.L.; Jenkins, G.D.; Kalari, K.; Lingle, W.; Petersen, G.; Lou, Z.; Wang, L. FKBP51 Affects Cancer Cell Response to Chemotherapy by Negatively Regulating Akt. Cancer Cell 2009, 16, 259-266. [CrossRef]

131. Qin, J.; Lee, H.-J.; Wu, S.-P.; Lin, S.-C.; Lanz, R.B.; Creighton, C.J.; DeMayo, F.; Tsai, S.Y.; Tsai, M.-J. Androgen Deprivation-Induced NCoA2 Promotes Metastatic and Castration-Resistant Prostate Cancer. J. Clin. Investig. 2014, 124, 5013-5026. [CrossRef] [PubMed]

132. Hammarsten, P.; Cipriano, M.; Josefsson, A.; Stattin, P.; Egevad, L.; Granfors, T.; Fowler, C.J. Phospho-Akt Immunoreactivity in Prostate Cancer: Relationship to Disease Severity and Outcome, Ki67 and Phosphorylated EGFR Expression. PLoS ONE 2012, 7, e47994. [CrossRef] [PubMed]

133. McCall, P.; Gemmell, L.K.; Mukherjee, R.; Bartlett, J.M.S.; Edwards, J. Phosphorylation of the Androgen Receptor Is Associated with Reduced Survival in Hormone-Refractory Prostate Cancer Patients. Br. J. Cancer 2008, 98, 1094-1101. [CrossRef] [PubMed]

134. Bedolla, R.; Prihoda, T.J.; Kreisberg, J.I.; Malik, S.N.; Krishnegowda, N.K.; Troyer, D.A.; Ghosh, P.M. Determining Risk of Biochemical Recurrence in Prostate Cancer by Immunohistochemical Detection of PTEN Expression and Akt Activation. Clin. Cancer Res. 2007, 13, 3860-3867. [CrossRef]

135. Kladney, R.D.; Cardiff, R.D.; Kwiatkowski, D.J.; Chiang, G.; Weber, J.; Arbeit, J.M.; Lu, Z.H. Tuberous Sclerosis Complex 1: An Epithelial Tumor Suppressor Essential to Prevent Spontaneous Prostate Cancer in Aged Mice. Cancer Res. 2010, 70, 8937-8947. [CrossRef] [PubMed]

136. Ma, L.; Teruya-Feldstein, J.; Behrendt, N.; Chen, Z.; Noda, T.; Hino, O.; Cordon-Cardo, C.; Pandolfi, P.P. Genetic Analysis of Pten and Tsc2 Functional Interactions in the Mouse Reveals Asymmetrical Haploinsufficiency in Tumor Sup-Pression. Genes Dev. 2005, 19, 1779-1786. [CrossRef]

137. Peterson, T.R.; Laplante, M.; Thoreen, C.C.; Sancak, Y.; Kang, S.A.; Kuehl, W.M.; Gray, N.S.; Sabatini, D.M. DEPTOR Is an mTOR Inhibitor Frequently Overexpressed in Multiple Myeloma Cells and Required for Their Survival. Cell 2009, 137, 873-886. [CrossRef]

138. Catena, V.; Bruno, T.; De Nicola, F.; Goeman, F.; Pallocca, M.; Iezzi, S.; Sorino, C.; Cigliana, G.; Floridi, A.; Blandino, G.; et al. Deptor Transcriptionally Regulates Endoplasmic Reticulum Homeostasis in Multiple Myeloma Cells. Oncotarget 2016, 7 , 70546-70558. [CrossRef] [PubMed]

139. Wang, Q.; Zhou, Y.; Rychahou, P.; Harris, J.W.; Zaytseva, Y.Y.; Liu, J.; Wang, C.; Weiss, H.L.; Liu, C.; Lee, E.Y.; et al. Deptor Is a Novel Target of Wnt/ $\beta$-Catenin/c-Myc and Contributes to Colorectal Cancer Cell Growth. Cancer Res. 2018, 78, $3163-3175$. [CrossRef] [PubMed]

140. Song, G.; Ouyang, G.; Bao, S. The Activation of Akt/PKB Signaling Pathway and Cell Survival. J. Cell. Mol. Med. 2005, 9, 59-71. [CrossRef] [PubMed] 
141. Datta, S.; Dudek, H.; Tao, X.; Masters, S.; Fu, H.; Gotoh, Y.; Greenberg, M.E. Akt Phosphorylation of BAD Couples Survival Signals to the Cell-Intrinsic Death Machinery. Cell 1997, 91, 231-241. [CrossRef]

142. Pilling, A.B.; Hwang, C. Targeting Prosurvival BCL2 Signaling through Akt Blockade Sensitizes Castration-Resistant Prostate Cancer Cells to Enzalutamide. Prostate 2019, 79, 1347-1359. [CrossRef] [PubMed]

143. Cardone, M.H.; Roy, N.; Stennicke, H.R.; Salvesen, G.S.; Franke, T.F.; Stanbridge, E.; Frisch, S.; Reed, J.C. Regulation of Cell Death Protease Caspase-9 by Phosphorylation. Science 1998, 282, 1318-1321. [CrossRef] [PubMed]

144. Kim, A.H.; Khursigara, G.; Sun, X.; Franke, T.F.; Chao, M.V. Akt Phosphorylates and Negatively Regulates Apoptosis SignalRegulating Kinase 1. Mol. Cell. Biol. 2001, 21, 893-901. [CrossRef]

145. Zhang, R.; Luo, D.; Miao, R.; Bai, L.; Ge, Q.; Sessa, W.C.; Min, W. Hsp90-Akt Phosphorylates ASK1 and Inhibits ASK1-Mediated Apoptosis. Oncogene 2005, 24, 3954-3963. [CrossRef]

146. Barthwal, M.; Sathyanarayana, P.; Kundu, C.N.; Rana, B.; Pradeep, A.; Sharma, C.; Woodgett, J.; Rana, A. Negative Regulation of Mixed Lineage Kinase 3 by Protein Kinase B/AKT Leads to Cell Survival. J. Biol. Chem. 2003, 278, 3897-3902. [CrossRef]

147. Park, H.-S.; Kim, M.-S.; Huh, S.-H.; Park, J.; Chung, J.; Kang, S.S.; Choi, E.-J. Akt (Protein Kinase B) Negatively Regulates SEK1 by Means of Protein Phosphorylation. J. Biol. Chem. 2002, 277, 2573-2578. [CrossRef] [PubMed]

148. Xie, D.; Gore, C.; Zhou, J.; Pong, R.-C.; Zhang, H.; Yu, L.; Vessella, R.L.; Min, W.; Hsieh, J.-T. DAB2IP Coordinates Both PI3K-Akt and ASK1 Pathways for Cell Survival and Apoptosis. Proc. Natl. Acad. Sci. USA 2009, 106, 19878-19883. [CrossRef]

149. Chen, H.; Toyooka, S.; Gazdar, A.F.; Hsieh, J.-T. Epigenetic Regulation of a Novel Tumor Suppressor Gene (hDAB2IP) in Prostate Cancer Cell Lines. J. Biol. Chem. 2003, 278, 3121-3130. [CrossRef]

150. Chen, H.; Tu, S.-W.; Hsieh, J.-T. Down-regulation of Human DAB2IP Gene Expression Mediated by Polycomb Ezh2 Complex and Histone Deacetylase in Prostate Cancer. J. Biol. Chem. 2005, 280, 22437-22444. [CrossRef] [PubMed]

151. Basu, S.; Totty, N.F.; Irwin, M.S.; Sudol, M.; Downward, J. Akt Phosphorylates the Yes-Associated Protein, YAP, to Induce Interaction with 14-3-3 and Attenuation of p73-Mediated Apoptosis. Mol. Cell 2003, 11, 11-23. [CrossRef]

152. Mayo, L.D.; Donner, D.B. A Phosphatidylinositol 3-Kinase/Akt Pathway Promotes Translocation of Mdm2 from the Cytoplasm to the Nucleus. Proc. Natl. Acad. Sci. USA 2001, 98, 11598-11603. [CrossRef]

153. Gottlieb, T.M.; Leal, J.F.; Seger, R.; Taya, Y.; Oren, M. Cross-Talk between Akt, p53 and Mdm2: Possible Implications for the Regulation of Apoptosis. Oncogene 2002, 21, 1299-1303. [CrossRef] [PubMed]

154. Zhou, B.P.; Hung, M.C. Novel Targets of Akt, p21CipI/WAF1, and MDM2. Semin Oncol. 2002, 29, 62-70. [CrossRef] [PubMed]

155. Liang, J.; Slingerland, J.M. Multiple Roles of the PI3K/PKB (Akt) Pathway in Cell Cycle Progression. Cell Cycle 2003, 2, 336-342. [CrossRef]

156. Testa, J.R.; Bellacosa, A. AKT Plays a Central Role in Tumorigenesis. Proc. Natl. Acad. Sci. USA 2001, 98, 10983-10985. [CrossRef] [PubMed]

157. Bellacosa, A.; Kumar, C.C.; Di Cristofano, A.; Testa, J.R. Activation of AKT Kinases in Cancer: Implications for Therapeutic Targeting. Adv Cancer Res 2005, 94, 29-86.

158. Khan, M.; Biswas, D.; Ghosh, M.; Mandloi, S.; Chakrabarti, S.; Chakrabarti, P. mTORC2 Controls Cancer Cell Survival by Modulating Gluconeogenesis. Cell Death Discov. 2015, 1, 15016. [CrossRef] [PubMed]

159. Goncharova, E.A.; Li, H.; Pimtong, W.; Lu, S.; Khavin, I.; Krymskaya, V.P. mTORC2 Is Required for Proliferation and Survival of TSC2-Null Cells. Mol. Cell. Biol. 2011, 31, 2484-2498. [CrossRef] [PubMed]

160. Kazyken, D.; Magnuson, B.; Bodur, C.; Acosta-Jaquez, H.A.; Zhang, D.; Tong, X.; Barnes, T.M.; Steinl, G.K.; Patterson, N.E.; Altheim, C.H.; et al. AMPK Directly Activates mTORC2 to Promote Cell Survival during Acute Energetic Stress. Sci. Signal. 2019, 12, eaav3249. [CrossRef]

161. Ruggero, D.; Sonenberg, N. The Akt of translational control. Oncogene 2005, 24, 7426-7434. [CrossRef] [PubMed]

162. Xu, Q.; Thompson, J.E.; Carroll, M. mTOR Regulates Cell Survival after Etoposide Treatment in Primary AML Cells. Blood 2005, 106, 4261-4268. [CrossRef] [PubMed]

163. Liu, Y.; Xu, H.; An, M. mTORC1 Regulates Apoptosis and Cell Proliferation in Pterygium via Targeting Autophagy and FGFR3. Sci. Rep. 2017, 7, 1-9. [CrossRef] [PubMed]

164. Morita, M.; Prudent, J.; Basu, K.; Goyon, V.; Katsumura, S.; Hulea, L.; Pearl, D.; Siddiqui, N.; Strack, S.; McGuirk, S.; et al. mTOR Controls Mitochondrial Dynamics and Cell Survival via MTFP1. Mol. Cell 2017, 67, 922-935. [CrossRef]

165. Oki, T.; Mercier, F.; Kato, H.; Jung, Y.; McDonald, T.O.; Spencer, J.A.; Mazzola, M.C.; van Gastel, N.; Lin, C.P.; Michor, F.; et al. Imaging Dynamic mTORC1 Pathway Activity In Vivo Reveals Marked Shifts That Support Time-Specific Inhibitor Therapy in AML. Nat. Commun. 2021, 12, 1-13. [CrossRef]

166. Meyuhas, O. Ribosomal Protein S6 Phosphorylation: Four Decades of Research. Int. Rev. Cell Mol. Biol. $2015,320,41-73$.

167. Jeon, Y.-J.; Kim, I.K.; Hong, S.-H.; Nan, H.; Kim, H.-J.; Lee, H.-J.; Masuda, E.S.; Meyuhas, O.; Oh, B.-H.; Jung, Y.-K. Ribosomal Protein S6 Is a Selective Mediator of TRAIL-Apoptotic Signaling. Oncogene 2008, 27, 4344-4352. [CrossRef]

168. Wittenberg, A.D.; Azar, S.; Klochendler, A.; Stolovich-Rain, M.; Avraham, S.; Birnbaum, L.; Gallimidi, A.B.; Katz, M.; Dor, Y.; Meyuhas, O. Phosphorylated Ribosomal Protein S6 Is Required for Akt-Driven Hyperplasia and Malignant Transformation, but Not for Hypertrophy, Aneuploidy and Hyperfunction of Pancreatic $\beta$-Cells. PLoS ONE 2016, 11, e0149995. [CrossRef]

169. Bitting, R.; Armstrong, A.J. Targeting the PI3K/Akt/mTOR Pathway in Castration-Resistant Prostate Cancer. Endocr. Relat. Cancer 2013, 20, 83-99. [CrossRef] 
170. Maira, S.M.; Pecchi, S.; Huang, A.; Burger, M.; Knapp, M.; Sterker, D.; Schnell, C.; Guthy, D.; Nagel, T.; Wiesmann, M.; et al. Identification and Characterization of NVP-BKM120, an Orally Available Pan-Class I PI3-Kinase Inhibitor. Mol. Cancer Ther. 2012, 11,317-328. [CrossRef]

171. Yadav, S.S.; Li, J.; Stockert, J.A.; O'Connor, J.; Herzog, B.; Elaiho, C.; Galsky, M.D.; Tewari, A.K.; Yadav, K.K. Combination Effect of Therapies Targeting the PI3K- and AR-Signaling Pathways in Prostate Cancer. Oncotarget 2016, 7, 76181-76196. [CrossRef] [PubMed]

172. Bendell, J.C.; Rodon, J.; Burris, H.A.; de Jonge, M.; Verweij, J.; Birle, D.; Demanse, D.; De Buck, S.S.; Ru, Q.C.; Peters, M.; et al. Phase I, Dose-Escalation Study of BKM120, an Oral Pan-Class I PI3K Inhibitor, in Patients with Advanced Solid Tumors. J. Clin. Oncol. 2012, 30, 282-290. [CrossRef]

173. Wipf, P.; Minion, D.J.; Halter, R.J.; Berggren, M.I.; Ho, C.B.; Chiang, G.G.; Kirkpatrick, L.; Abraham, R.; Powis, G. Synthesis and Biological Evaluation of Synthetic Viridins Derived From C(20)-Heteroalkylation of the Steroidal PI-3-Kinase Inhibitor Wortmannin. Org. Biomol. Chem. 2004, 2, 1911-1920. [CrossRef] [PubMed]

174. Hotte, S.J.; Chi, K.N.; Joshua, A.; Tu, D.; Macfarlane, R.J.; Gregg, R.W.; Ruether, J.D.; Basappa, N.S.; Finch, D.; Salim, M.; et al. A Phase II Study of PX-866 in Patients with Recurrent or Metastatic Castration-resistant Prostate Cancer: Canadian Cancer Trials Group Study IND205. Clin. Genitourin. Cancer 2019, 17, 201-208. [CrossRef] [PubMed]

175. Bhutani, J.; Sheikh, A.; Niazi, A.K. Akt Inhibitors: Mechanism of Action and Implications for Anticancer Therapeutics. Infect. Agent Cancer 2013, 8, 49. [CrossRef]

176. Brown, J.S.; Banerji, U. Maximising the Potential of AKT Inhibitors as Anti-Cancer Treatments. Pharmacol. Ther. 2016, 172, 101-115. [CrossRef]

177. Hu, Y.; Qiao, L.; Wang, S.; Rong, S.-B.; Meuillet, E.J.; Berggren, M.; Gallegos, A.; Powis, G.; Kozikowski, A.P. 3-(Hydroxymethyl)Bearing Phosphatidylinositol Ether Lipid Analogues and Carbonate Surrogates Block PI3-K, Akt, and Cancer Cell Growth. J. Med. Chem. 2000, 43, 3045-3051. [CrossRef]

178. Luo, Y.; Smith, R.A.; Guan, R.; Liu, X.; Klinghofer, V.; Shen, J.; Hutchins, C.; Richardson, P.; Holzman, T.; Rosenberg, S.H.; et al. Pseudosubstrate Peptides Inhibit Akt and Induce Cell Growth Inhibition. Biochemistry 2004, 43, 1254-1263. [CrossRef]

179. Barnett, S.F.; Bilodeau, M.T.; Lindsley, C.W. The Akt/PKB Family of Protein Kinases: A Review of Small Molecule Inhibitors and Progress towards Target Validation. Curr. Top. Med. Chem. 2005, 5, 109-125. [CrossRef]

180. Floryk, D.; Thompson, T.C. Perifosine Induces Differentiation and Cell Death in Prostate Cancer Cells. Cancer Lett. 2008, 266, 216-226. [CrossRef]

181. Festuccia, C.; Gravina, G.L.; Muzi, P.; Millimaggi, D.; Dolo, V.; Vicentini, C.; Bologna, M. Akt Down-Modulation Induces Apoptosis of Human Prostate Cancer Cells and Synergizes with EGFR Tyrosine Kinase Inhibitors. Prostate 2008, 68, 965-974. [CrossRef]

182. Posadas, E.M.; Gulley, J.L.; Arlen, P.M.; Trout, A.; Parnes, H.L.; Wright, J.; Lee, M.-J.; Chung, E.J.; Trepel, J.B.; Sparreboom, A.; et al. A Phase II Study of Perifosine in Androgen Independent Prostate Cancer. Cancer Biol. Ther. 2005, 4, 1133-1137. [CrossRef]

183. Hirai, H.; Sootome, H.; Nakatsuru, Y.; Miyama, K.; Taguchi, S.; Tsujioka, K.; Ueno, Y.; Hatch, H.; Majumder, P.K.; Pan, B.-S.; et al. MK-2206, an Allosteric Akt Inhibitor, Enhances Antitumor Efficacy by Standard Chemotherapeutic Agents or Molecular Targeted Drugs In vitro and In vivo. Mol. Cancer Ther. 2010, 9, 1956-1967. [CrossRef] [PubMed]

184. Thomas, C.; Lamoureux, F.; Crafter, C.; Davies, B.R.; Beraldi, E.; Fazli, L.; Kim, S.; Thaper, D.; Gleave, M.E.; Zoubeidi, A. Synergistic Targeting of PI3K/AKT Pathway and Androgen Receptor Axis Significantly Delays Castration-Resistant Prostate Cancer Progression In Vivo. Mol. Cancer Ther. 2013, 12, 2342-2355. [CrossRef] [PubMed]

185. Davies, B.R.; Greenwood, H.; Dudley, P.; Crafter, C.; Yu, D.-H.; Zhang, J.; Li, J.; Gao, B.; Ji, Q.; Maynard, J.; et al. Preclinical Pharmacology of AZD5363, an Inhibitor of AKT: Pharmacodynamics, Antitumor Activity, and Correlation of Monotherapy Activity with Genetic Background. Mol. Cancer Ther. 2012, 11, 873-887. [CrossRef] [PubMed]

186. Kolinsky, M.; Rescigno, P.; Bianchini, D.; Zafeiriou, Z.; Mehra, N.; Mateo, J.; Michalarea, V.; Riisnaes, R.; Crespo, M.; Figueiredo, I.; et al. A Phase I Dose-Escalation Study of Enzalutamide in Combination with the AKT Inhibitor AZD5363 (Capivasertib) in Patients with Metastatic Castration-Resistant Prostate Cancer. Ann. Oncol. 2020, 31, 619-625. [CrossRef] [PubMed]

187. Crabb, S.J.; Birtle, A.J.; Martin, K.; Downs, N.; Ratcliffe, I.; Maishman, T.; Ellis, M.; Griffiths, G.; Thompson, S.; Ksiazek, L.; et al. ProCAID: A Phase I Clinical Trial to Combine the AKT Inhibitor AZD5363 with Docetaxel and Prednisolone Chemotherapy for Metastatic Castration Resistant Prostate Cancer. Investig. New Drugs 2017, 35, 599-607. [CrossRef]

188. Burris, H.A.; Siu, L.L.; Infante, J.R.; Wheler, J.J.; Kurkjian, C.; Opalinska, J.; Smith, D.A.; Antal, J.M.; Gauvin, J.L.; Gonzalez, T.; et al. Safety, Pharmacokinetics (PK), Pharmacodynamics (PD), and Clinical Activity of the Oral AKT Inhibitor GSK2141795 (GSK795) in a Phase I First-in-Human Study. J. Clin. Oncol. 2011, 29, 3003. [CrossRef]

189. Aghajanian, C.; Bell-McGuinn, K.M.; Burris, H.A., 3rd; Siu, L.L.; Stayner, L.A.; Wheler, J.J.; Hong, D.S.; Kurkjian, C.; Pant, S.; Santiago-Walker, A.; et al. A Phase I, Open-Label, Two-Stage Study to Investigate the Safety, Tolerability, Pharmacokinetics, and Pharmaco-Dynamics of the Oral AKT Inhibitor GSK2141795 in Patients with Solid Tumors. Investig. New Drugs 2018, 36, 1016-1025. [CrossRef]

190. Chandarlapaty, S.; Sawai, A.; Scaltriti, M.; Rodrik-Outmezguine, V.; Grbovic-Huezo, O.; Serra, V.; Majumder, P.K.; Baselga, J.; Rosen, N. AKT Inhibition Relieves Feedback Suppression of Receptor Tyrosine Kinase Expression and Activity. Cancer Cell 2011, 19, 58-71. [CrossRef] 
191. Majumder, P.K.; Febbo, P.G.; Bikoff, R.; Berger, R.; Xue, Q.; McMahon, L.M.; Manola, J.; Brugarolas, J.; McDonnell, T.J.; Golub, T.R.; et al. mTOR Inhibition Reverses Akt-Dependent Prostate Intraepithelial Neoplasia through Regulation of Apoptotic and HIF-1-Dependent Pathways. Nat. Med. 2004, 10, 594-601. [CrossRef] [PubMed]

192. Amato, R.J.; Jac, J.; Mohammad, T.; Saxena, S. Pilot Study of Rapamycin in Patients with Hormone-Refractory Prostate Cancer. Clin. Genitourin. Cancer 2008, 6, 97-102. [CrossRef]

193. George, D.J.; Halabi, S.; Healy, P.; Jonasch, D.; Anand, M.; Rasmussen, J.; Wood, S.Y.; Spritzer, C.; Madden, J.F.; Armstrong, A.J. Phase 2 Clinical Trial of TORC1 Inhibition with Everolimus in Men with Metastatic Castration-Resistant Prostate Cancer. Urol. Oncol. 2020, 38, 79.e15-79.e22. [CrossRef] [PubMed]

194. Armstrong, A.J.; Netto, G.J.; Rudek, M.A.; Halabi, S.; Wood, D.P.; Creel, P.A.; Mundy, K.; Davis, S.L.; Wang, T.; Albadine, R.; et al. A Pharmacodynamic Study of Rapamycin in Men with Intermediate- to High-Risk Localized Prostate Cancer. Clin. Cancer Res. 2010, 16, 3057-3066. [CrossRef] [PubMed]

195. Sarbassov, D.D.; Ali, S.M.; Sengupta, S.; Sheen, J.-H.; Hsu, P.P.; Bagley, A.F.; Markhard, A.L.; Sabatini, D.M. Prolonged Rapamycin Treatment Inhibits mTORC2 Assembly and Akt/PKB. Mol. Cell 2006, 22, 159-168. [CrossRef] [PubMed]

196. Yip, C.K.; Murata, K.; Walz, T.; Sabatini, D.M.; Kang, S.A. Structure of the Human mTOR Complex I and Its Implications for Rapamycin Inhibition. Mol. Cell 2010, 38, 768-774. [CrossRef]

197. Sparks, C.A.; Guertin, D.A. Targeting mTOR: Prospects for mTOR Complex 2 Inhibitors in Cancer Therapy. Oncogene 2010, 29, 3733-3744. [CrossRef] [PubMed]

198. Hsieh, A.C.; Liu, Y.; Edlind, M.P.; Ingolia, N.T.; Janes, M.R.; Sher, A.; Shi, E.Y.; Stumpf, C.; Christensen, C.; Bonham, M.J.; et al. The Translational Landscape of mTOR Signalling Steers Cancer Initiation and Metastasis. Nature 2012, 485, 55-61. [CrossRef]

199. Graham, L.; Banda, K.; Torres, A.; Carver, B.S.; Chen, Y.; Pisano, K.; Shelkey, G.; Curley, T.; Scher, H.I.; Lotan, T.; et al. A Phase II Study of the Dual mTOR Inhibitor MLN0128 in Patients with Metastatic Castration Resistant Prostate Cancer. Investig. New Drugs 2018, 36, 458-467. [CrossRef] [PubMed]

200. Li, S.; Sheng, J.; Liu, Z.; Fan, Y.; Zhang, C.; Lv, T.; Hu, S.; Jin, J.; Yu, W.; Song, Y. Potent Antitumour of the mTORC1/2 Dual Inhibitor AZD2014 in Docetaxel-Sensitive and Docetaxel-Resistant Castration-Resistant Prostate Cancer Cells. J. Cell Mol. Med. 2021, 25, 2436-2449. [CrossRef]

201. Maira, S.-M.; Stauffer, F.; Brueggen, J.; Furet, P.; Schnell, C.; Fritsch, C.; Brachmann, S.; Chène, P.; De Pover, A.; Schoemaker, K.; et al. Identification and Characterization of NVP-BEZ235, a New Orally Available Dual Phosphatidylinositol 3-Kinase/Mammalian Target of Rapamycin Inhibitor with Potent In Vivo Antitumor Activity. Mol. Cancer Ther. 2008, 7, 1851-1863. [CrossRef]

202. Wallin, J.J.; Edgar, K.A.; Guan, J.; Berry, M.; Prior, W.W.; Lee, L.; Lesnick, J.D.; Lewis, C.; Nonomiya, J.; Pang, J.; et al. GDC-0980 Is a Novel Class I PI3K/mTOR Kinase Inhibitor with Robust Activity in Cancer Models Driven by the PI3K Pathway. Mol. Cancer Ther. 2011, 10, 2426-2436. [CrossRef]

203. Luszczak, S.; Simpson, B.S.; Stopka-Farooqui, U.; Sathyadevan, V.K.; Echeverria, L.M.C.; Kumar, C.; Costa, H.; Haider, A.; Freeman, A.; Jameson, C.; et al. Co-Targeting PIM and PI3K/mTOR Using Multikinase Inhibitor AUM302 and a Combination of AZD-1208 and BEZ235 in Prostate Cancer. Sci. Rep. 2020, 10, 14380. [CrossRef] [PubMed]

204. Burris, H.; Rodon, J.; Sharma, S.; Herbst, R.S.; Tabernero, J.; Infante, J.R.; Silva, A.; Demanse, D.; Hackl, W.; Baselga, J. First-inHuman Phase I Study of the Oral PI3K Inhibitor BEZ235 in Patients (Pts) with Advanced Solid Tumors. J. Clin. Oncol. 2010, 28, 3005. [CrossRef]

205. Massard, C.; Chi, K.N.; Castellano, D.; de Bono, J.; Gravis, G.; Dirix, L.; Machiels, J.-P.; Mita, A.; Mellado, B.; Turri, S.; et al. Phase Ib Dose-Finding Study of Abiraterone Acetate Plus Buparlisib (BKM120) or Dactolisib (BEZ235) in Patients with Castration-Resistant Prostate Cancer. Eur. J. Cancer 2017, 76, 36-44. [CrossRef] [PubMed]

206. Wagner, A.J.; Bendell, J.C.; Dolly, S.; Morgan, J.A.; Ware, J.A.; Fredrickson, J.; Mazina, K.E.; Lauchle, J.O.; Burris, H.A.; De Bono, J.S. A First-in-Human Phase I Study to Evaluate GDC-0980, an Oral PI3K/mTOR Inhibitor, Administered QD in Patients with Advanced Solid Tumors. J. Clin. Oncol. 2011, 29, 3020. [CrossRef]

207. Qian, D.Z.; Rademacher, B.L.; Pittsenbarger, J.; Huang, C.-Y.; Myrthue, A.; Higano, C.S.; Garzotto, M.; Nelson, P.S.; Beer, T.M. CCL2 Is Induced by Chemotherapy and Protects Prostate Cancer Cells from Docetaxel-Induced Cytotoxicity. Prostate 2009, 70, 433-442. [CrossRef] [PubMed]

208. Bozulic, L.; Surucu, B.; Hynx, D.; Hemmings, B.A. PKBalpha/Akt1 Acts Downstream of DNA-PK in the DNA Double-Strand Break Response and Promotes Survival. Mol. Cell 2008, 30, 203-213. [CrossRef] [PubMed]

209. Brown, K.K.; Montaser-Kouhsari, L.; Beck, A.H.; Toker, A. MERIT40 Is an Akt Substrate that Promotes Resolution of DNA Damage Induced by Chemotherapy. Cell Rep. 2015, 11, 1358-1366. [CrossRef] [PubMed]

210. Wendel, H.-G.; De Stanchina, E.; Fridman, J.S.; Malina, A.; Ray, S.; Kogan, S.; Cordon-Cardo, C.; Pelletier, J.; Lowe, S.W. Survival Signalling by Akt and eIF4E in Oncogenesis and Cancer Therapy. Nature 2004, 428, 332-337. [CrossRef] [PubMed]

211. VanderWeele, D.; Zhou, R.; Rudin, C.M. Akt Up-Regulation Increases Resistance to Microtubule-Directed Chemotherapeutic Agents through Mammalian Target of Rapamycin. Mol. Cancer Ther. 2004, 3, 1605-1613. [PubMed]

212. Schayowitz, A.; Sabnis, G.; Goloubeva, O.; Njar, V.C.; Brodie, A.M. Prolonging Hormone Sensitivity in Prostate Cancer Xenografts through Dual Inhibition of AR and mTOR. Br. J. Cancer 2010, 103, 1001-1007. [CrossRef]

213. Nakabayashi, M.; Werner, L.; Courtney, K.D.; Buckle, G.; Oh, W.K.; Bubley, G.J.; Hayes, J.H.; Weckstein, D.; Elfiky, A.; Sims, D.M.; et al. Phase II Trial of RAD001 and Bicalutamide for Castration-Resistant Prostate Cancer. BJU Int. 2012, 110, 1729-1735. [CrossRef] 
214. Chow, H.; Ghosh, P.M.; deVere White, R.; Evans, C.P.; Dall'Era, M.A.; Yap, S.A.; Li, Y.; Beckett, L.A.; Lara, P.N., Jr.; Pan, C.X. A Phase 2 Clinical Trial of Everolimus Plus Bicalutamide for Castration-Resistant Prostate Cancer. Cancer 2016, 122, 1897-1904. [CrossRef] [PubMed]

215. De Bono, J.S.; De Giorgi, U.; Rodrigues, D.N.; Massard, C.; Bracarda, S.; Font, A.; Arija, J.A.A.; Shih, K.C.; Radavoi, G.D.; Xu, N.; et al. Randomized Phase II Study Evaluating Akt Blockade with Ipatasertib, in Combination with Abiraterone, in Patients with Metastatic Prostate Cancer with and without PTEN Loss. Clin. Cancer Res. 2018, 25, 928-936. [CrossRef] [PubMed]

216. Braglia, L.; Zavatti, M.; Vinceti, M.; Martelli, A.M.; Marmiroli, S. Deregulated PTEN/PI3K/AKT/mTOR Signaling in Prostate Cancer: Still a Potential Druggable Target? Biochim. Biophys. Acta Mol. Cell Res. 2020, 1867, 118731. [CrossRef] [PubMed]

217. Bertacchini, J.; Mediani, L.; Beretti, F.; Guida, M.; Ghalali, A.; Brugnoli, F.; Bertagnolo, V.; Petricoin, E.; Poti, F.; Arioli, J.; et al. Clusterin Enhances AKT2-Mediated Motility of Normal and Cancer Prostate Cells through a PTEN and PHLPP1 Circuit. J. Cell. Physiol. 2018, 234, 11188-11199. [CrossRef] [PubMed]

218. Crumbaker, M.; Khoja, L.; Joshua, A.M. AR Signaling and the PI3K Pathway in Prostate Cancer. Cancers 2017, 9, 34. [CrossRef] [PubMed] 